Prepared for the U.S. Department of Energy

under Contract DE-AC05-76RL01830

\title{
PinBus Interface Design
}

\author{
DJ Hammerstrom RM Pratt \\ JD Adgerson RG Pratt \\ C Sastry
}

November 2009

Pacific Northwest

NATIONAL LABORATORY

Proudly Operated by Battelle Since 1965 


\title{
DISCLAIMER
}

This report was prepared as an account of work sponsored by an agency of the United States Government. Neither the United States Government nor any agency thereof, nor Battelle Memorial Institute, nor any of their employees, makes any warranty, express or implied, or assumes any legal liability or responsibility for the accuracy, completeness, or usefulness of any information, apparatus, product, or process disclosed, or represents that its use would not infringe privately owned rights. Reference herein to any specific commercial product, process, or service by trade name, trademark, manufacturer, or otherwise does not necessarily constitute or imply its endorsement, recommendation, or favoring by the United States Government or any agency thereof, or Battelle Memorial Institute. The views and opinions of authors expressed herein do not necessarily state or reflect those of the United States Government or any agency thereof.

\author{
PACIFIC NORTHWEST NATIONAL LABORATORY \\ operated by \\ BATTELLE \\ for the \\ UNITED STATES DEPARTMENT OF ENERGY \\ under Contract DE-AC05-76RL01830
}




\title{
PinBus Interface Design
}

\author{
DJ Hammerstrom RM Pratt \\ JD Adgerson RG Pratt \\ C Sastry
}

November 2009

Prepared for

the U.S. Department of Energy

under Contract DE-AC05-76RL01830

Pacific Northwest National Laboratory

Richland, Washington 99352 



\begin{abstract}
On behalf of the U.S. Department of Energy, Pacific Northwest National Laboratory has explored and expanded upon a simple control interface that might have merit for the inexpensive communication of smart-grid operational objectives, such as demand response, to small electric end-use devices and appliances. The approach relies on bi-directional communication via the electrical voltage states of from one to eight shared interconnection pins. The name "PinBus" has been suggested and adopted for the proposed interface protocol. The protocol is defined through the presentation of state diagrams and the pins' functional definitions. Both simulations and laboratory demonstrations are being conducted to demonstrate the elegance and power of the suggested approach. PinBus supports a very high degree of interoperability across its interfaces, allowing innumerable pairings of devices and communication protocols and supporting the practice of practically any smart-grid use case.
\end{abstract}




\section{Acronyms and Abbreviations}

AMI

API

DR

GFA

GWAC

HAN

MPU

PHEV

PLC

PNNL

TOU

USB

U-SNAP advanced metering infrastructure

application program interface

demand response

Grid Friendly ${ }^{\mathrm{TM}}$ appliance

GridWise ${ }^{\circledR}$ Architecture Council

home area network

microprocessor unit

plug-in hybrid electric vehicle

power line carrier

Pacific Northwest National Laboratory

time of use

Universal Serial Bus

Utility Smart Network Access Port 


\section{Contents}

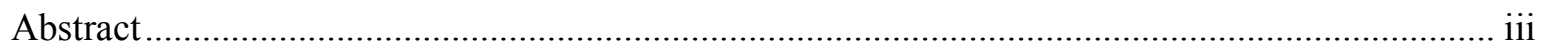

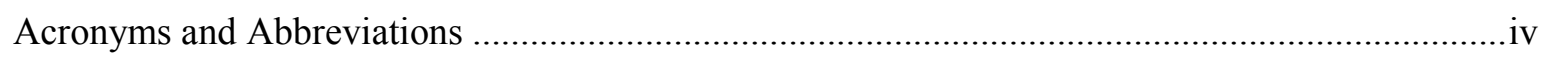

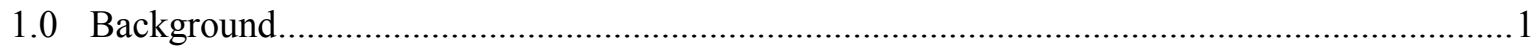

2.0 Existing Device-Interface Issues Addressed by PinBus .....................................................

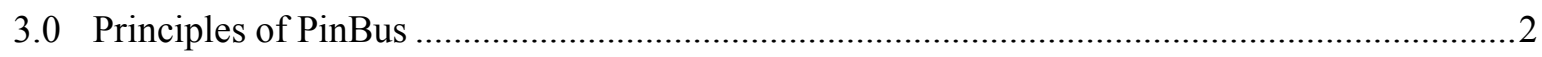

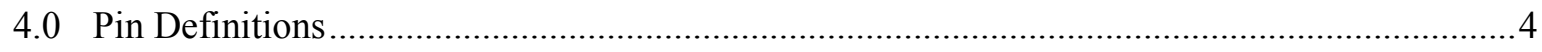

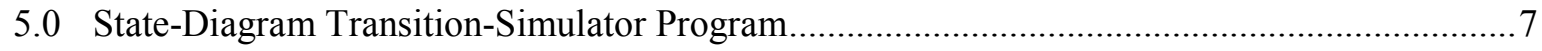

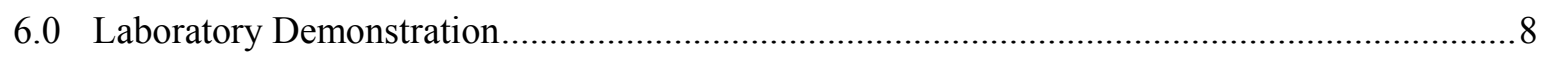

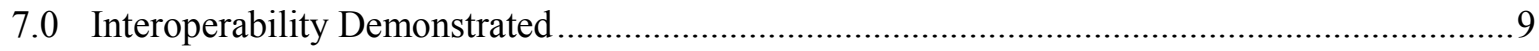

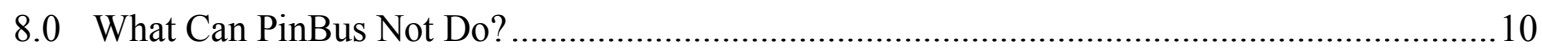

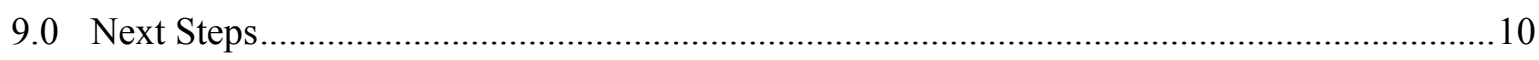

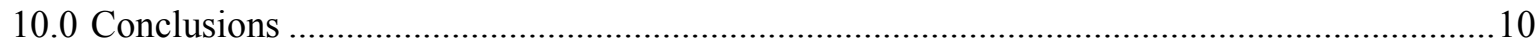

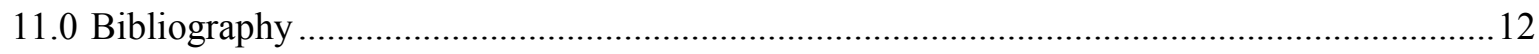

Appendix A : PinBus Pin Definitions - Utility Perspective ...................................................... 1

Appendix B : PinBus Pin Definitions - Device Perspective....................................................... B.1

Appendix C : Load PinBus State Diagrams .........................................................................

Appendix D: Utility PinBus State Diagrams ....................................................................... D. 1

Appendix E: Block Diagram - HAN System with PinBus Interfaces ....................................... E.1

Appendix F: Interpretation of PinBus Pin Transactions ........................................................... 1

Appendix G: Table of Grid Responses of Interest ......................................................................

Appendix H: GWAC Stack Assessment of PinBus ................................................................

Appendix I: Block Diagram - PinBus Interoperability Demonstration ...................................... I.1 


\section{Figures}

Figure 1. Components of a PinBus System.

Figure 2. Simplified PinBus State Diagram Showing the Full 15 Allowed States and TransitionsError! Bookmark not de

Figure A.1. Pin Definitions from the Utility-Side Perspective A.1

Figure B.1. Pin Definitions from the Device-Side Perspective............................ 1

Figure C.1. Load Device State Diagram One-Pin Implementation..............................1

Figure C.2. Load Device State Diagram Two-Pin Implementation ........................................... C.2

Figure C.3. Load Device State Diagram Three-, Four-, and Five-Pin Implementations ............... C.3

Figure C.4. Load Device State Diagram Six-Pin Implementation............................................... .4

Figure C.5. Load Device State Diagram Seven- and Full Eight-Pin Implementation ................. C.5

Figure D.1. Utility Control State Diagram One-Pin Implementation........................ 1

Figure D.2. Utility Control State Diagram Two-Pin Implementation......................................... D.2

Figure D.3. Utility Control State Diagram Three- Four-, and Five-Pin implementations ............. D.3

Figure D.4. Utility Control State Diagram Six-Pin Implementation........................................ D.4

Figure D.5. Utility Control State Diagram Seven- and Full Eight-Pin Implementations ............. D.5

Figure E.1. One Vision of How the PinBus Interface Protocol could Fit into Larger Smart Grid

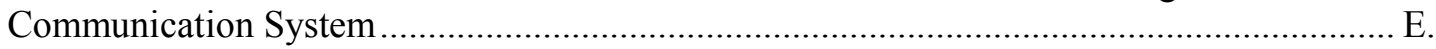

Figure I.1. Bock Diagram of Planned Laboratory Demonstration Components ............................ I.1 


\section{Tables}

Table 1. Communication Options for Utility and Device Sides Available with Various Numbers

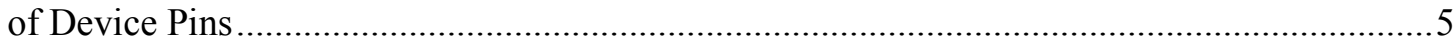

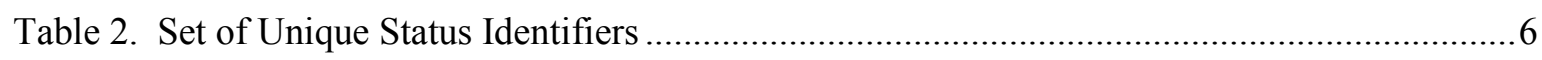

Table 3. Tentative Pin Interpretations within a Device Identifier...............................................

Table F.1. Exemplary Interpretations of Pin State Transitions.................................1

Table G.1. Responses Available from Various Appliance Types................................ 1

Table H.1. Conformance to GridWise ${ }^{\mathrm{TM}}$ Architecture Council (GWAC) Stack (Blue-Device Responsibility; Green —Device Interface Responsibility; Purple_-Premises Responsibility; Yellow_Utility Entity Responsibility) ............................................... 



\subsection{Background}

The PinBus interface protocol is based on the successful communication of autonomously generated control signals to appliances during the Grid Friendly ${ }^{\mathrm{TM}}$ Appliance Project (Hammerstrom et al. 2007). In this project, 150 Whirlpool Corporation clothes dryers and 50 water heaters were modified to receive and respond to a signal from Pacific Northwest National Laboratory's Grid Friendly ${ }^{\mathrm{TM}}$ controller. The magnitude of a shared pin's voltage was simply reduced to zero to indicate the presence of a lowfrequency condition on the electric power grid. Recognizing how elegantly the simple control signal had been communicated by the electrical voltage state of a limited number of pins, collaborators from Pacific Northwest National Laboratory, Whirlpool Corporation, and Portland General Electric explained the approach's attributes and presented a compelling business case for the approach at the 2007 Grid-Interop Forum (Eustis, Horst, and Hammerstrom et al. 2007).

The development of this interface protocol is being undertaken during a global push to make electric power grids smarter. There is a consequent desire to create more flexible, responsive populations of enduse devices - a cooperative grid system that better manages available energy, power, and infrastructure. Ideally, the development of such a flexible, responsive system will be facilitated by low-cost means of communication to the multitude of potentially responsive end-use devices. Components of such a system that are interoperable and interchangeable are preferred because they facilitate competition which further drives downward the system costs. Furthermore, such communications must be secure. The PinBus approach is very responsive to these needs of a smart grid.

\subsection{Existing Device-Interface Issues Addressed by PinBus}

The control of small devices like appliances can add only a small expense. At pennies per $\mathrm{kWh}$, the expense of energy and electric power justifies few demand-response applications. Therefore, utility energy programs typically control only the largest types of residential appliances. Even so, the expenses borne by retrofit products and aftermarket engineering and installation make such programs only marginally cost-effective. . Installation expenses would be greatly reduced if necessary modifications were performed on the manufacturing floor, where labor is relatively inexpensive. Devices would be ready to respond to energy programs, and more and even smaller devices like white-goods appliances could be made responsive to the grid.

Devices like appliances endure much longer than nearly any digital technology or protocol has proven to endure. The smart grid involves the application of digital intelligence-computers - throughout the power grid. But there is a fundamental mismatch between the life expectancies of grid hardware and the very short life expectancies of most digital electronic devices and their software and protocols. PinBus requires minimal digital technology on the device side of its interface. Instead, digital intelligence is to be applied external to the responsive device, perhaps as part of a replaceable module that may be later replaced or updated.

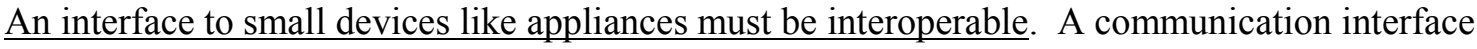
should be identically applied to all devices. Interfaces providing different communication protocols and media and made by different vendors should be interchangeable and applicable to all device types and 
models. And each interface should be amenable to multiple existing and future use cases. The PinBus approach accepts the development of interchangeable interface modules that support different communication protocols and media. PinBus enforces that use cases be translated to a limited set of device-independent signals that can be communicated via its limited number of pin states.

The interface must be secure from intentional and accidental threats. Communication itself has been shown to increase threats from malicious and accidental sources. PinBus minimizes communication at its device interface. It disallows communication of device-specific information that is not necessarily communicated.

\subsection{Principles of PinBus}

A PinBus system comprises

- a responsive device that provides the PinBus interface

- a removable, interchangeable interface module that converts the PinBus signals into another standard communication protocol

- an entity that communicates to the interface module.

Examples of entities that would communicate to the interface modules include utilities, aggregators, home gateways, or home energy managers. The responsive devices may include either electric loads or distributed generators, including renewable generators.

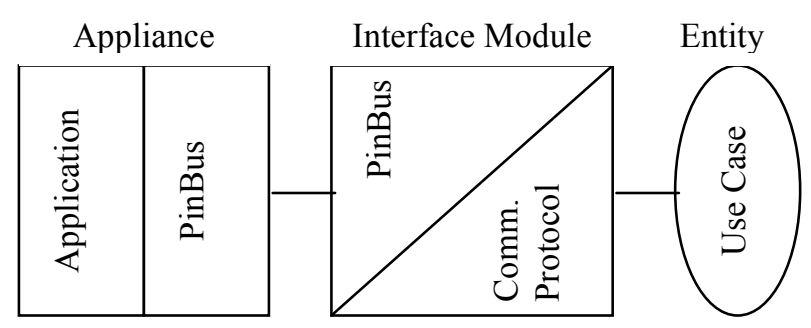

Figure 1. Components of a PinBus System

PinBus communication is inherently bi-directional. The wired-OR physical protocol of the pins avoids bus conflicts. In wired-OR logic, any terminus may assert a zero by forcing the state of the wire to zero potential, but no party may assert a " 1 " state. Therefore, any party may assert its own zero and may read zeros asserted by other parties that share the connection. In principle, more than two parties could share the PinBus bus, but that extension will be deferred for a later version. The advantage of allowing multiple parties to share the PinBus bus would be that multiple applications - say from a local home manger, neighborhood manager, autonomous controller, and utility - could all benefit from responses of a shared device.

PinBus protocol allows and supports device communication using from one to eight device pins. Very simple devices like water heaters can respond adequately using just one pin. Additional pins allow for richer interactions, including acknowledgements, device identification, service requests, and communication of price-level bids and incentives. While the devices can be configured for fewer than 
eight pins, every interface module must be able to communicate with any device and must therefore support communication on all eight pins. When an interface module is connected to a device that has a reduced pin count, it learns the number of device pins and simplifies its own communications to use only those pins that are available on the device.

PinBus supports bid and price behaviors of the type needed for transactive control. Transactive control is a dynamic, interactive system of pricing control in which devices bid their availability or need for power, which in turn affects the closed-loop price that is distributed to the responsive devices (Hammerstrom et al. 2007b).

PinBus communicates objectives and outcomes, not device-specific directives. One of the keys to the simplification provided by PinBus is its recognition that the electric power grid asks responsive devices to perform relatively simple and few tasks. While some competing protocols provide bandwidth for the specific control of device components (e.g., "turn off dryer heating element"), PinBus communicates only high level objectives (e.g., "the grid is short on available power", or "the grid needs VAr support immediately for a short time"). The responsive devices respond with simple acknowledgements and bids that reveal their availability and need for power. PinBus communicates nothing that is device-specific and therefore does not itself rely on unique addressing.

The PinBus approach could prove to be the least-expensive approach to achieving demand-responseready devices. The PinBus approach pushes risks and expenses outside the appliance or device. A new appliance should be inexpensively augmented to support PinBus. The application engineer has options for numbers of pins to support and can implement the simplest interface without a microprocessor. It is assumed that the most economical way to provide PinBus is to install it during manufacture. Modest expenses are then incurred through the application of the universal interface modules, but these expenses would be borne by those who wish to control the device and only for the devices that are actually used. Additional savings should be expected from the universality of the approach and its endurance as a simple standard; for example, development would be expedited because there is no need for the device developer to reveal and negotiate contextual and semantic meanings of communicated signals.

PinBus allows for various levels of device processor intelligence, including none. A one-pin device may be implemented with direct control of a power relay. Simple applications can be designed with logic only and no microprocessor. The PinBus approach is reducible to an application-specific integrated circuit that would further simplify the application developers' development tasks. Process-oriented devices, especially those that interact regularly with humans, would likely require richer control and microprocessors.

PinBus respects the inviolability of the device manufacturers' customer relationship. The manufacturer is solely responsible for determining the best response available from his product models. The PinBus protocol allows the device owner to temporarily override requested responses. Nonetheless, energy program mangers can ask for and receive acknowledgements through PinBus that devices are available and responding.

The provision of power through the PinBus interface is still being investigated and should be resolved for later versions.

Physical connectors have been defined conceptually, but must be fully specified in later versions. 
PinBus interface modules are identical for all applications. This means that there should be only one (e.g., ZigBee ${ }^{\mathbb{B}}$-to-PinBus) interface module rather than unique versions of such module by device type and by energy program. This is an important key to interoperability.

Simplicity strengthens security. Because PinBus is unable to communicate unique identifying information across its boundaries, it should not be as vulnerable to cyber-security threats as are other protocols that rely on rich serial communication of specific, identifiable information.

\subsection{Pin Definitions}

A table defining the PinBus pin interpretations from the perspectives of the device and the utility sides can be found in Appendices A and B.

The interpretation of a pin's meaning depends on one's perspective. The meaning of a pin's state must be inferred from both the utility and device sides. As will be discussed in the next section, the device and utility sides may assert pins that transition from one state to another, which transition is interpreted by the other side of the interface. Because wired-OR logic has been employed, the device or interface module sides need only sample the pins to quickly assess any pin conditions that are being asserted by the other side. Therefore, the most important pin 7, for example, may be used by the device to show whether its application is consuming energy and by the utility side to request an energy response. Perspective must be considered.

Each pin has an assigned attribute, or assigned attributes, that it is responsible to convey. One pin conveys to the device whether an energy response is in effect; another pin is used by the utility side to request a bid and acknowledgement from the device. While more data could be communicated if the pins simply represented a byte of data (i.e., up to 256 unique bytes), that approach would have (1) precluded the use of fewer than 8 pins, (2) limited the bi-directional communication across the bus, and (3) violated an important principle and advantage of PinBus, which was to avoid the communication of rich, devicespecific information.

An interface module must support the full set of eight pins, but device applications are permitted to use as few as one pin. The interface module infers the number of pins from device responses and thereafter reduces the complexity of its communications according to the number of active pins provided by the device. The capabilities of utility and devices that can be communicated across the PinBus with various number of device pins are summarized in Table 1. 
Table 1. Communication Options for Utility and Device Sides Available with Various Numbers of Device Pins

\begin{tabular}{|c|c|c|}
\hline \# of Pins & Utility Side & Device Side \\
\hline 1 & Power-curtailment requests & Reveal on/off status \\
\hline 2 & Hold power-curtailment requests & Acknowledge power-curtailment requests \\
\hline & & Reveal override of power-curtailment requests \\
\hline $3-5$ & Bi-directional real-power requests & Acknowledge bi-directional real-power requests \\
\hline & Reveal 2-8 price or value levels & Bid for service using 2-8 discrete levels \\
\hline 6 & Bi-directional reactive-power requests & $\begin{array}{l}\text { Acknowledge bi-directional reactive-power } \\
\text { requests }\end{array}$ \\
\hline $7-8$ & Reveal duration and urgency of requests & Alert system / request service \\
\hline
\end{tabular}

It is most expedient to define PinBus communications by a state diagram as is shown in Figure 1. The lines between the 15 states represent the important pin and originator of the state transition. For example "D[P6]" indicates that the device (D), not the utility side (U), initiates the transition, and it is the status of pin number 6 that is used to initiate or reverse the transition.

The three unique pairings of numbers (described below) that accompany the states were useful in determining the number of unique and important states, and might prove useful during future application development. The three numbers are the operational, notification, and response status:

- Operational status - whether the device is active (i.e., on) or not. The device is solely responsible for determining its operational status, but the operational status can be influenced or directly controlled by response requests received by the device. The device operational status is "active," "inactive," or "unknown."

- Notification status - whether the device or utility sides have requested notification. Either the device or utility side can initiate notification. Most often, no notification will be asserted or requested and the notification status will be "idle." However, the device can initiate an override-and-identify condition to let the utility side know its identifier, which is a pin condition that reveals the capabilities of the device, and sometimes to announce that a request has been overridden. The utility side can request acknowledgement and bids from the device. The assertion and release of a notification state by either the device or utility side should be followed by a notification request from the other side. Thereby, the notification requests can be used to invite a bid or identification notification across the interface.

- Response status - the utility side may assert a request for a modification of real-power consumption, reactive-power consumption, or both real- and reactive-power consumption. If no response is being requested by the utility side, the response status remains "idle." The device may acknowledge or choose to override the requested change in real or reactive power, but these responses by the device do not change the response status.

These status attributes and are defined and enumerated in Table 2. The status numbers shown in Table 2 can be used in conjunction with the shown pairings of three numbers in each of the states of Figure 1 in the order (operational, notification, response). 
Table 2. Set of Unique Status Identifiers

\begin{tabular}{c|c|c|c|c|c}
\hline Status & $\mathbf{0}$ & $\mathbf{1}$ & $\mathbf{2}$ & $\mathbf{3}$ & $\mathbf{4}$ \\
\hline Operational & Unknown & On/Active & Off/Inactive & Not Allowed & - \\
\hline Notification & Unknown & Acknowledge and Bid & Override and Identify & Not Allowed & Idle \\
\hline Response & Unknown & Real-Power Request & $\begin{array}{c}\text { Reactive-Power } \\
\text { Request }\end{array}$ & $\begin{array}{c}\text { Both Real- and } \\
\text { Reactive-Power } \\
\text { Request }\end{array}$ & Idle \\
\hline
\end{tabular}

The available states into which the device or interface module (on the utility side) can be transitioned are determined by the present state, by the number of pins supported by the present device, and by whether the transition is to be initiated from the device or utility side. The complete set of diagrams of allowable states has been included in Appendices C and D. In almost every case, a transition that is initiated by one side of the interface will be properly recognized by the other. There are several counterexamples where the transition cannot be uniquely determined when few device pins are used, but the ramifications of this ambiguity are not serious.

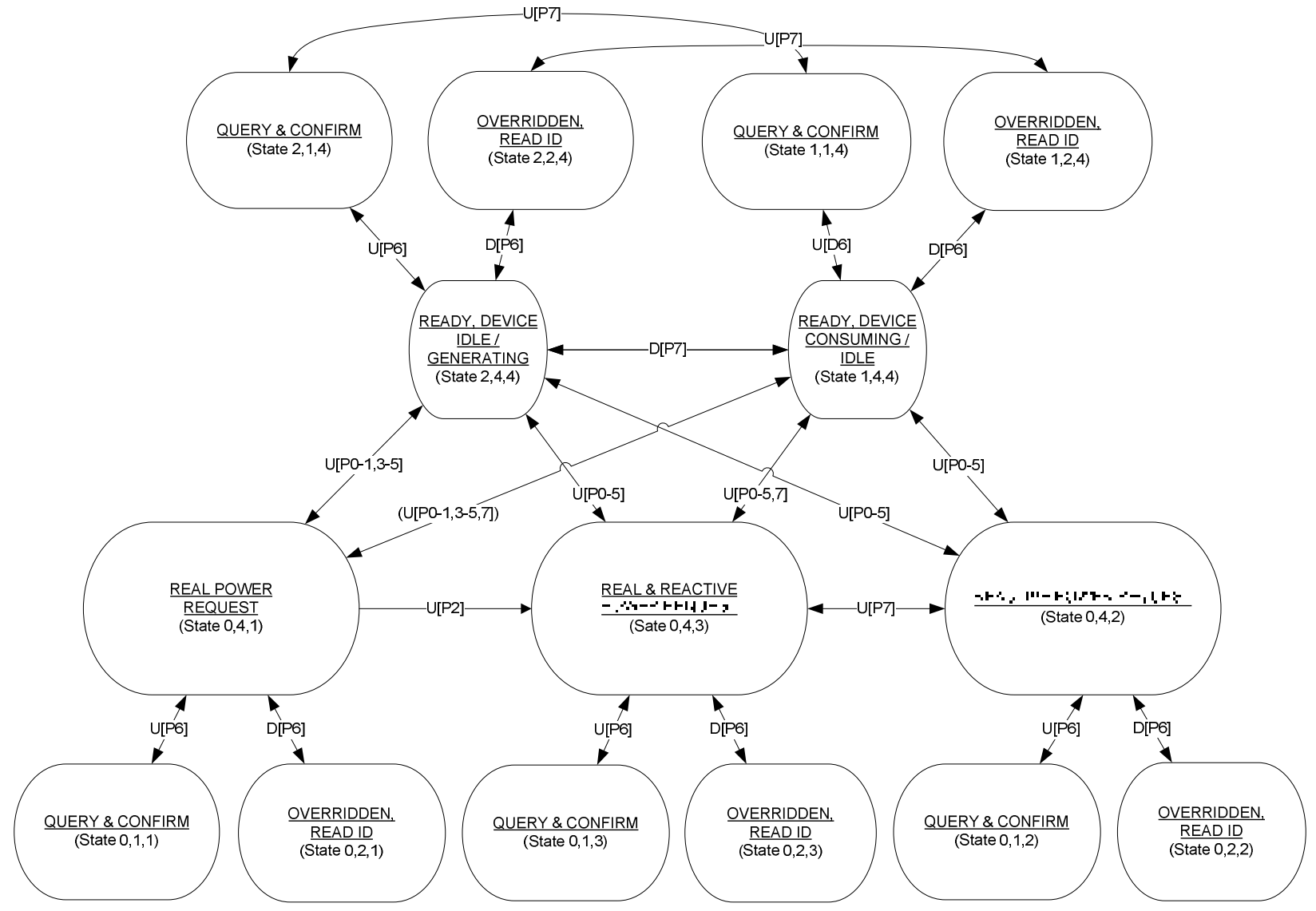

Figure 2. Simplified PinBus State Diagram Showing the Full 15 Allowed States and Transitions 
Note also that the device that has been used here to teach the PinBus approach in these state diagrams is an electric load. There is a subtle change in the interpretation of some pins for generation resource devices, as is shown in the pin-definition diagrams in the Appendices A and B. These distinctions are the result of defining pins by the needs of the power grid. For example, a generator will bid high when its power is not readily available, but a load will bid high when it needs power. As another example, a load sets pin 7 high when it is on; a generator sets pin 7 high when it is off. In this way, the utility side may assert the pin low to both turn off the load and turn on the generator, demonstrating a shortage of power to be resolved by loads and generators alike.

The interface module must infer the number of device pins being used by the device. This is done indirectly, from information embedded in the device identifier. The device identifier necessarily ends with a 0 (asserted low state) and thus points to the last supported pin. The remaining pins of the identifier have been assigned tentative meanings (see Table 3), but the interpretation of device identifiers has not yet been finalized. Note that a device's identifier identifies its response capabilities and does not attempt to assign a unique identifying number.

Table 3. Tentative Pin Interpretations within a Device Identifier

\begin{tabular}{r|l}
\hline $\mathbf{x x}-111111$ & Default device identifier \\
AND 11-xxxxxx & Simple one- or two-pin interface \\
AND 11-0xxxxx & Simple three-pin interface \\
AND 11-10xxxx & Simple four-pin interface \\
AND \$DF & Device offers supply or storage (4) \\
AND 11-110xxx & Simple 5-pin interface \\
AND \$EF & Device is bid- and price-responsive (5) \\
AND 11-1110xx & Simple 6-pin interface \\
AND \$F7 & Device offers both real and reactive responses (6) \\
AND 11-11110x & Simple 7-pin interface \\
AND \$FB & Device offers autonomous responses (7) \\
AND 11-111110 & Simple 8-pin interface \\
AND \$FD & Device offers status indicators on its user interface (8) \\
\hline
\end{tabular}

\subsection{State-Diagram Transition-Simulator Program}

An animated PinBus state-transition emulator was developed during 2009 using Microsoft Visio. This emulator demonstrates how transitions may be initiated by the device or utility sides and how the resultant PinBus bits should be interpreted across the interface. If there is continuing interest in PinBus, this emulator could be interfaced with responsive appliances to demonstrate such applications. 


\subsection{Laboratory Demonstration}

A laboratory demonstration of the PinBus approach has been formulated. The purpose is to demonstrate

- how small devices like appliances may be configured to provide a useful PinBus interface

- how various interchangeable interface modules can be produced to interface between PinBus-enabled appliances and existing communication protocols like $\operatorname{ZigBee}^{\circledR}$ (2009), $\operatorname{HomePlug}^{\circledR}$ (2009), or U-SNAP (2009a, 2009b).

The laboratory demonstration components consist of

- a thermostat hijacker - a thermostat base has been designed to intercept and modify the control signals from a conventional programmable thermostat. The thermostat continues to operate as before, but the thermostat base can modify its behaviors based on information communicated via PinBus.

- a water-heater hijacker - water-heater control is communicated via a single PinBus pin. A retrofit controller is attached to a conventional 50-gallon electric water heater to control water heater energy consumption. The on/off status of the water heater is provided through external metering.

- A ZigBee-to-PinBus interface module - the utility-side PinBus interface is translated to and from ZigBee protocols (ZigBee 2009), providing one means for control of an appliance through a home area network.

- A Grid Friendly ${ }^{\mathrm{TM}}$-to-PinBus interface module - to show the breadth over which PinBus might become implemented, PinBus is interfaced to the autonomous Pacific Northwest National Laboratory Grid Friendly appliance controller so that a PinBus appliance can be made responsive to underfrequency and other grid conditions detected.

- Various use cases to be enacted by the system to include traditional demand response, dynamically transactive price responsiveness, and autonomous control.

The PinBus appliance demonstrations are intended to demonstrate a possible path forward for the technology. To become accepted as a standardized approach, PinBus must be adopted and used by the appliance-manufacturing community. To provide cost-effective demand responses, the interfaces must be installed on devices like appliances during the manufacturing process.

The specific PinBus devices were selected to represent a noteworthy range of complexity. A thermostat necessarily uses at least 5 PinBus pins to support full bidding and price responsiveness. This device will demonstrate nearly all the functionality now proposed for fully communicating thermostats that use rich serial communications; the utility and thermostat communities are incorrect in asserting that such rich serial communications are necessary.

The critical test of a PinBus thermostat is whether it can support transactive control of the type that was demonstrated during the Olympic Peninsula Project (Hammerstrom et al. 2007b). To participate in transactive control, a thermostat must be able not only to respond to price levels, but it must also bid its present need for power. This can be accomplished via PinBus if (1) price is translated into distinct levels upstream by an energy manager (e.g., natural price levels would be "high," "low," "normal," "a bargain"), 
and (2) the device's need for power can be converted to a bid level, as was demonstrated during the Olympic Peninsula Project (Hammerstrom et al. 2007b).

At the other extreme, a water heater is a simple electric load that will not greatly benefit from additional pins and will respond quite adequately while supporting only one PinBus pin. Even simpler devices (e.g., a toaster) could be controlled via PinBus without requiring even a microprocessor for the device application.

We have also tried to represent diverse interoperability opportunities through our selection of interface modules. Several radio and power-line communication standards have received favorable recognition in the smart-grid arena. Most present efforts toward defining home area networks have focused on fairly specific device-to-device communication. The challenge has been to develop an interface module that translates between that device-to-device communication and the results-oriented signals of PinBus.

Using a PinBus interface module to interface appliances with autonomous controllers like the Grid Friendly controller is an innovative step. We propose that this approach is a sensible compromise between installing such a controller in every device application, and communicating a centralized signal to such devices.

Smart-grid practitioners have come to call each of their energy-program applications (like thermostat setback or water-heater curtailment) a use case. We adopt that term. Our demonstration will consist of at least two such use cases - perhaps selected from among traditional direct demand response, transactive price control, and autonomous underfrequency control.

\subsection{Interoperability Demonstrated}

PinBus will be shown to be interoperable at multiple levels in ways unparalleled. Furthermore, the demonstration of such interoperability is quite simple. First, if two different use cases are run with two devices and their respective interface modules, a level of interoperability across multiple use cases is thereby demonstrated; that is, the same embodiment supports multiple use cases. Contrast this with the traditional practice of programming individual energy programs for each device set. Next, if the interface modules applied to the appliance devices are swapped, a demonstration of all eight possible pairings between two devices, two interface module types, and two use cases is completed. This level of interoperability is unprecedented:

- PinBus may be applied similarly across a set of diverse devices

- Interchangeable interface modules can be made to translate between diverse communication protocols and PinBus-enabled devices. Furthermore, these devices may be applied identically to any PinBusenabled device.

- A means has been demonstrated to support multiple, simultaneous, diverse use cases using one interface for all use cases. 


\subsection{What Can PinBus Not Do?}

PinBus accomplishes many objectives for grid-responsive devices, but it cannot satisfy all needs or desires for device interfaces:

- PinBus does not support rich serial communication of the type necessary to directly communicate with displays; however, it does have the potential to control typical indicators on displays (e.g., a critical peak price indicator).

- PinBus does not directly receive and respond to price. Price must be interpreted externally to the interface according to a limited number of discrete price levels before price can be acted upon through a PinBus interface.

- PinBus does not support explicit, directed device responses. It instead allows a device manufacturer to determine the best responses for up to eight levels of real-power requests and up to eight levels of reactive-power requests.

\subsection{Next Steps}

The PinBus interface approach is counter to prevailing approaches, which now favor rich serial communication to and from all responsive devices. A level of industry interest and acceptance should be obtained before continuation of this protocol development. However, while there are innumerable competing serial protocols in this space, and the smart-grid industry is not close to consensus on any complete protocol that will service all present and future devices, the definition of PinBus provided in this white paper is already $80 \%$ complete at most interoperability levels. Physical implementation and verification of PinBus protocol has also begun. This means that PinBus could be adopted and used very soon without requiring much debate at the technical and informational interoperability levels.

PinBus should perhaps be combined with a simple serial communication interface like U-SNAP. In this pairing, the physical interface should support both PinBus and U-SNAP. PinBus would be mandatory, but U-SNAP communications would be also supported by some applications like energy portals that will require serial communication.

Regardless, a physical interface must be selected for PinBus. An optically-isolated interface would be preferred to provide necessary isolation between the interchangeable external modules and devices that have 120- and 240-VAC supplies. If possible, the device should also provide an isolated 24-VAC (or other) power supply through the PinBus physical interface.

\subsection{Conclusions}

This white paper and its appendices provide a nearly complete specification for a novel smart-grid interface between the interests of the power grid and small electrical loads like appliances and controllable distributed-generation resources. The PinBus interface is unconventional in that it uses the electrical voltage states of from one to eight pins to communicate to and from devices, rather than using rich serial communication, as is the prevailing practice. Nonetheless, the interface supports the 
communication of price signals and requests for more, or less, real or reactive power. PinBus devices are able to acknowledge such requests and can bid accordingly for the rights to consume (or produce) real or reactive power.

The PinBus interface protocol is truly interoperable. It supports many use cases and communication protocols and can be practiced on devices ranging in complexity from a simple water heater to a communicating, price-transactive thermostat. Very simple devices may interpret the PinBus logic without microprocessors. The interface modules are interchangeable between device applications without modification. The level of interoperability demonstrated by PinBus is unprecedented.

While the PinBus approach does have limitations (for example, it does not support energy monitors), it shows promise as an inexpensive interface between the power grid and an army of small electric loads and generators. Especially intriguing is the recommended pairing of PinBus with simple serial communications, which interface would accommodate both simple and complex serial communication to devices. 


\subsection{Bibliography}

Eustis, C, GR Horst, and DJ Hammerstrom. 2007. “Appliance Interface for Grid Responses," in Proc. of the Grid Interop Forum, Nov. 7-9, 2007.

GridWise Architecture Council. 2008. “GridWise ${ }^{\circledR}$ Interoperability Context-Setting Framework, Version 1." GridWise Architecture Council, March 2008. Available online at http://www.gridwiseac.org/about/publications.aspx.

Hammerstrom D, J Brous, G Horst, T Oliver, C Eustis, OM Järvegren, RG Pratt, R Kajfasz, P Michie, W Marek, and RL Munson. 2007a. Pacific Northwest GridWise ${ }^{\mathrm{TM}}$ Testbed Demonstration Projects; Part II. Grid Friendly ${ }^{\mathrm{TM}}$ Appliance Project. PNNL-17079, Pacific Northwest National Laboratory, Richland, WA. Available at http://gridwise.pnl.gov.

Hammerstrom DJ, R Ambrosio, TA Carlon, DP Chassin, JG DeSteese, RT Guttromson, OM Järvegren, R Kajfasz, S Katipamula, P Michie, T Oliver, and RG Pratt. 2007b. Pacific Northwest GridWise Testbed Projects: Part 1. Olympic Peninsula Project, Technical Report PNNL-17167, Pacific Northwest National Laboratory. Richland, Washington. October 2007. Available at http://gridwise.pnl.gov.

HomePlug. 2009. HomePlug ${ }^{\circledR}$ Powerline Alliance. Available online at http://www.homeplug.org/home/. U-SNAP. 2009a. "U-SNAPTM Alliance: Enabling the Device Ecosystem for the Smart Grid." U-SNAP Alliance. Available online at http://usnap.org/.

U-SNAP. 2009b. “U-SNAP Serial Interface Specification, Version 1.” U-SNAP Alliance. Available online at http://usnap.org/technical.aspx.

ZigBee. 2009. ZigBee ${ }^{\circledR}$ Alliance. Available online at http://www.zigbee.org/. 


\section{Appendix A}

\section{PinBus Pin Definitions - Utility Perspective}





\section{Appendix A: PinBus Pin Definitions - Utility Perspective}

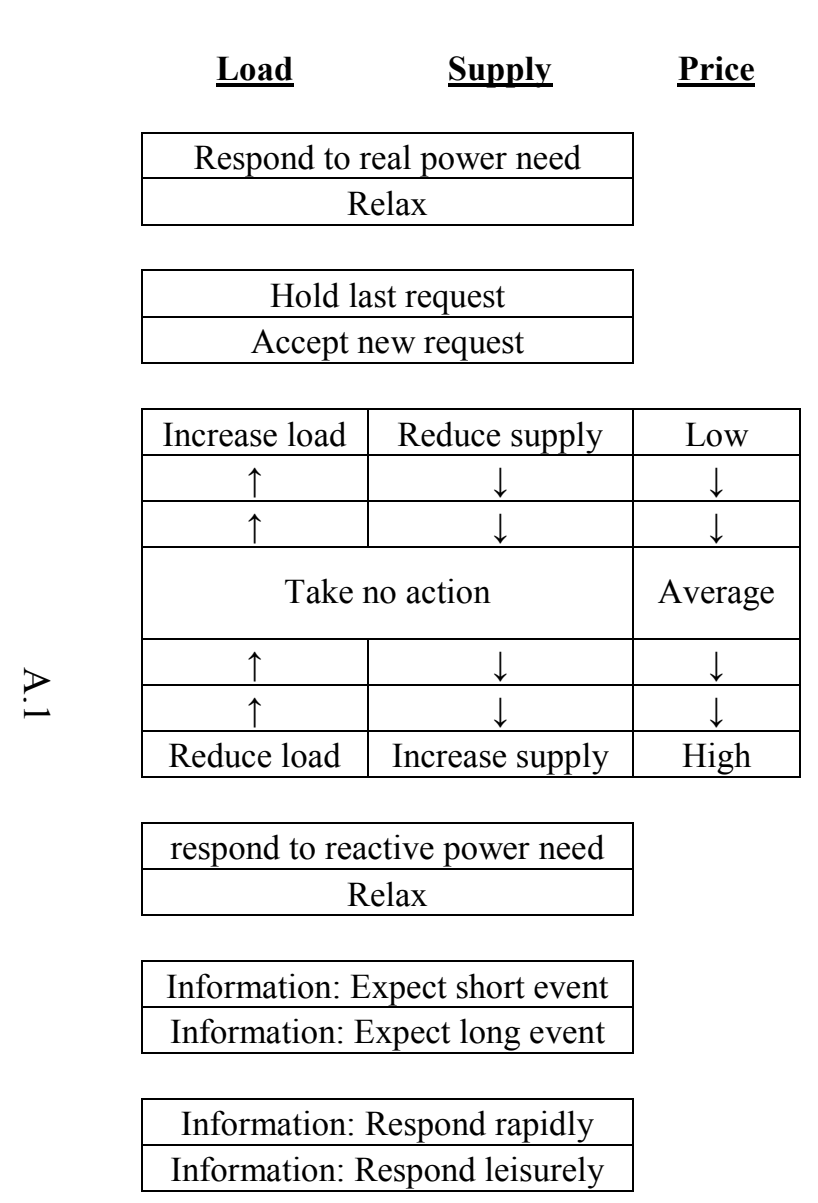

Utility Requests:

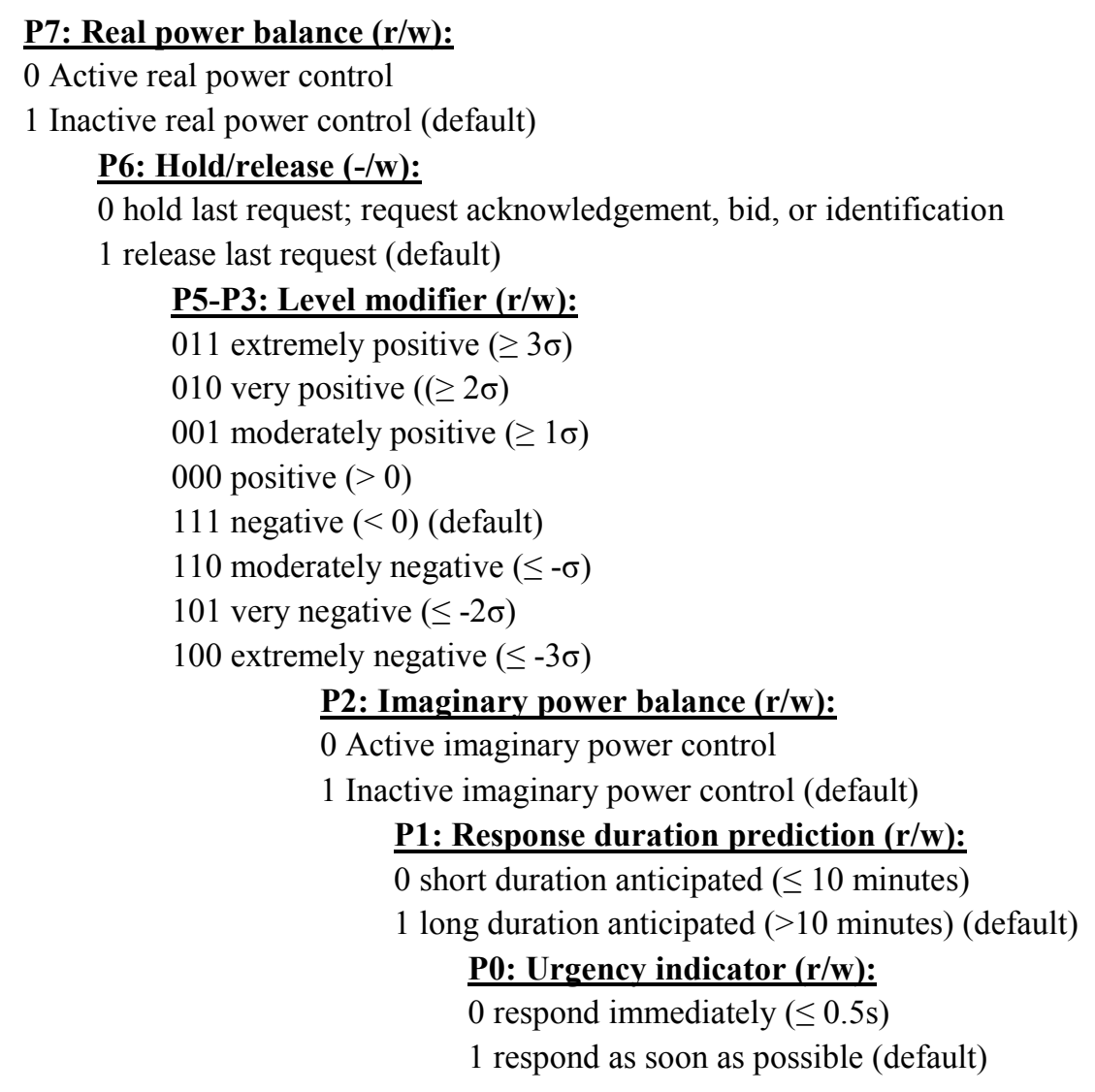

Bits:

\begin{tabular}{|l|l|l|l|l|l|}
\hline P7 & P6 & P5P4P3 & P2 & P1 & P0 \\
\hline
\end{tabular}

Figure A.1. Pin Definitions from the Utility-Side Perspective 



\section{Appendix B}

PinBus Definitions - Device Perspective 



\section{Appendix B: PinBus Pin Definitions - Device Perspective}

Bits: $\quad$\begin{tabular}{l|l|l|l|l|l|} 
P7 & P6 & P5P4P3 & P2 & P1 & P0 \\
\cline { 2 - 4 }
\end{tabular}
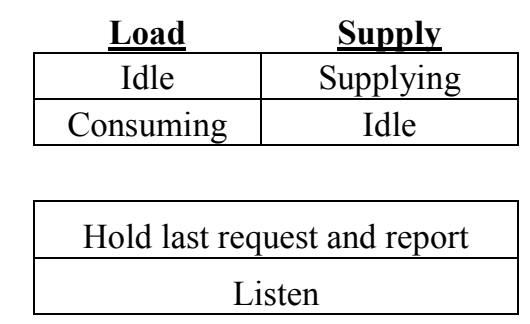

\begin{tabular}{|c|c|}
\hline High bid & Low bid \\
\hline (unsatisfied) & (available) \\
\hline$\uparrow$ & $\downarrow$ \\
$\leftarrow-$ & \multicolumn{2}{|c|}{ Average bid } \\
\hline$\uparrow$ & $\downarrow$ \\
\hline (satisfied) & (unavailable) \\
\hline Low bid & High bid \\
\hline
\end{tabular}

\section{Acknowledge}

Idle, ignore, or override

Acknowledge

Idle, ignore, or override

Service requested $\mathrm{OK}$

\section{Device Responses:}

P7: Active / inactive indicator (r/w):

0 load is idle, supply is active

1 load is active, supply is idle

\section{P6: Hold/release (r/-):}

0 not listening / overridden

1 listening for further requests

P5-P3: Level modifier; device identifier bit ( $r / w)$ :

$$
\begin{aligned}
& 011 \text { extremely positive }(\geq 3 \sigma) \\
& 010 \text { very positive }((\geq 2 \sigma) \\
& 001 \text { moderately positive }(\geq 1 \sigma) \\
& 000 \text { positive }(>0) \\
& 111 \text { negative }(<0)(\text { default }) \\
& 110 \text { moderately negative }(\leq-\sigma) \\
& 101 \text { very negative }(\leq-2 \sigma) \\
& 100 \text { extremely negative }(\leq-3 \sigma)
\end{aligned}
$$

P2: Ack. reactive power request; device identifier bit (r/w):

0 acknowledge reactive power control request

1 do not acknowledge, perhaps override reactive power control (default)

P1: Ack. real power request; device identifier bit (r/w):

0 acknowledge real power control request

1 do not acknowledge, real power control overridden (default)

P0: Service request; device identifier bit (r/w):

0 need service

1 ok (default)

Figure B.1. Pin Definitions from the Device-Side Perspective 

Appendix C

\section{Load PinBus State Diagrams}





\section{Appendix C: Load PinBus State Diagrams}

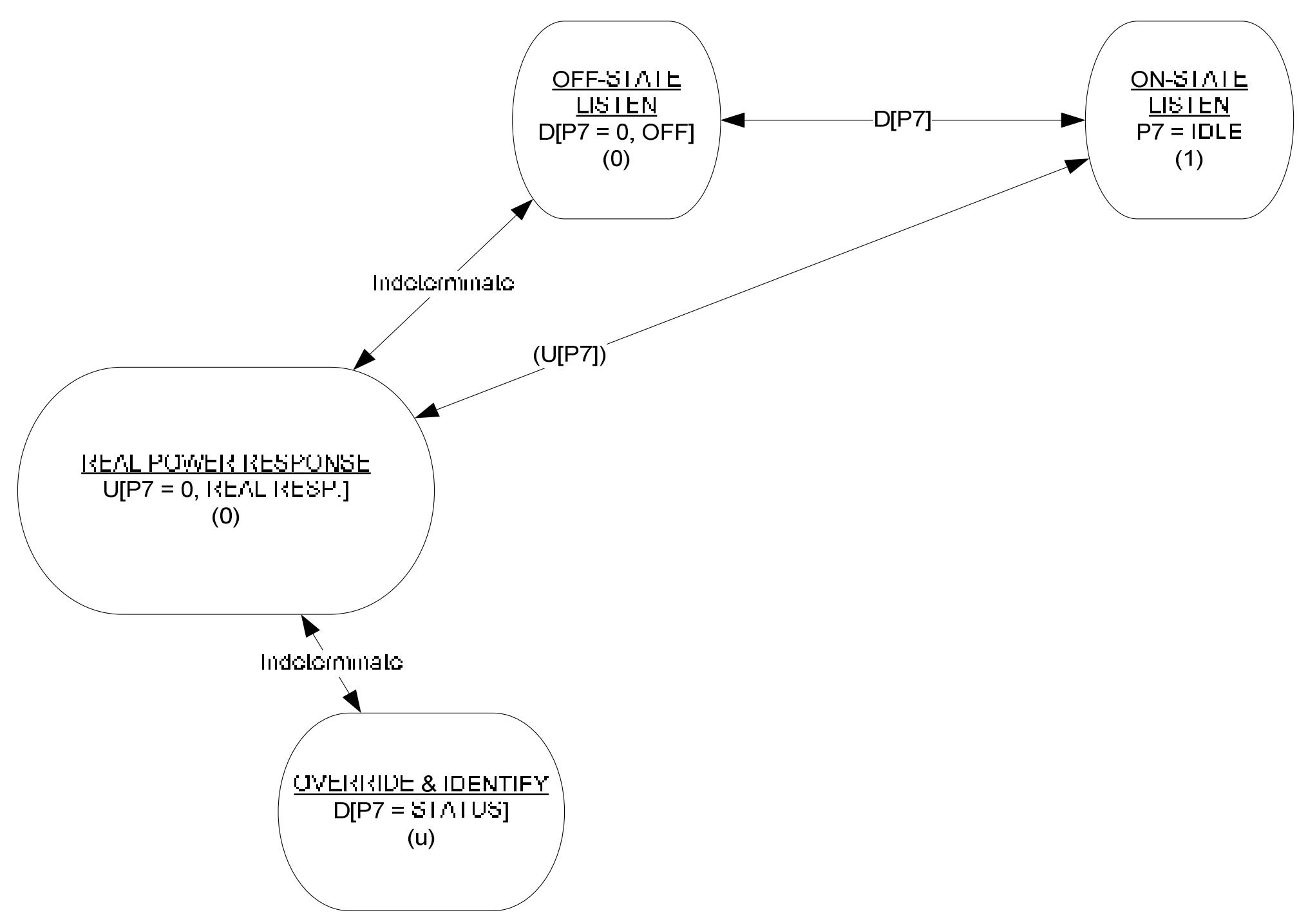

Figure C.1. Load Device State Diagram One-Pin Implementation 


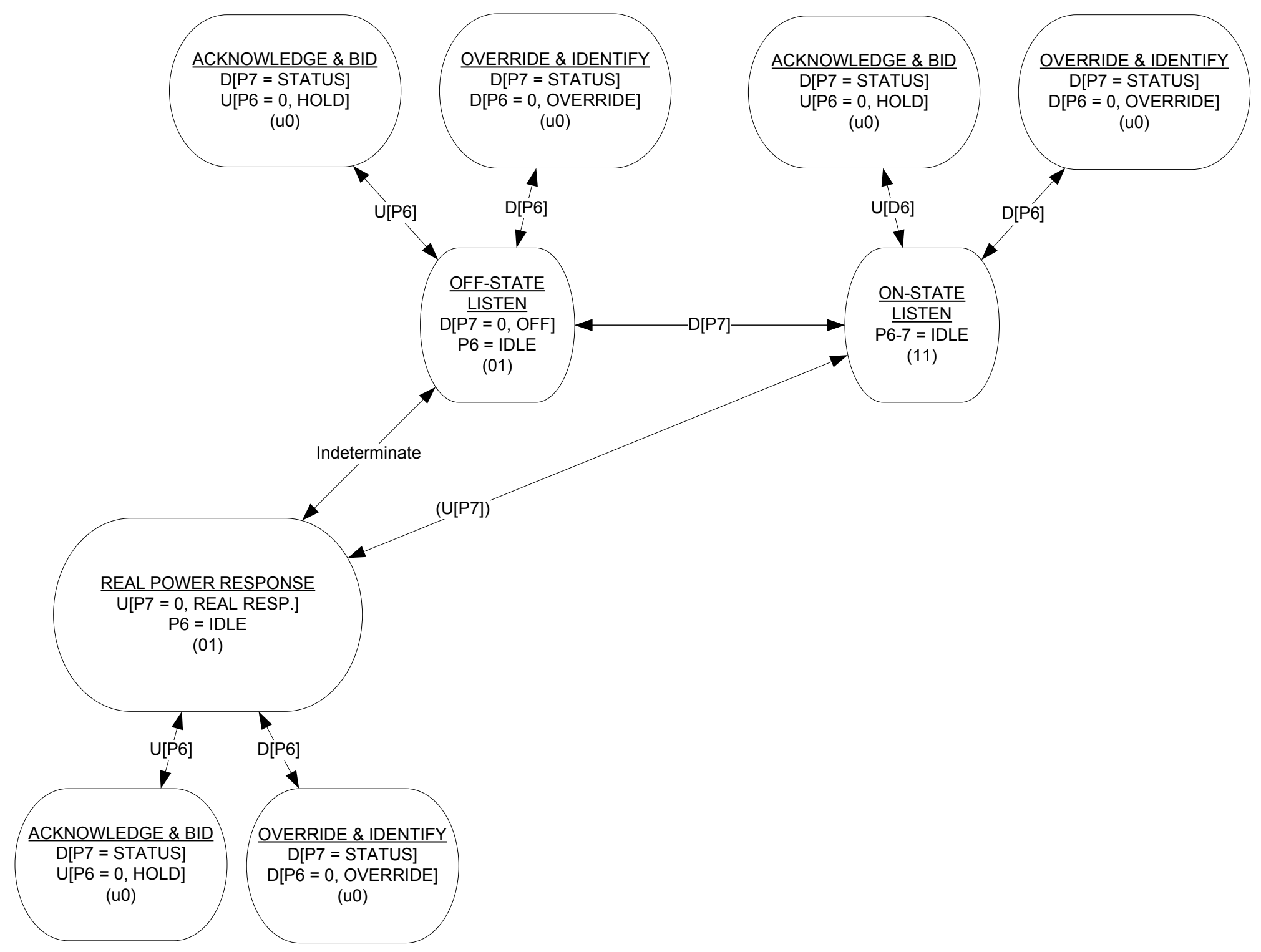

Figure C.2. Load Device State Diagram Two-Pin Implementation 


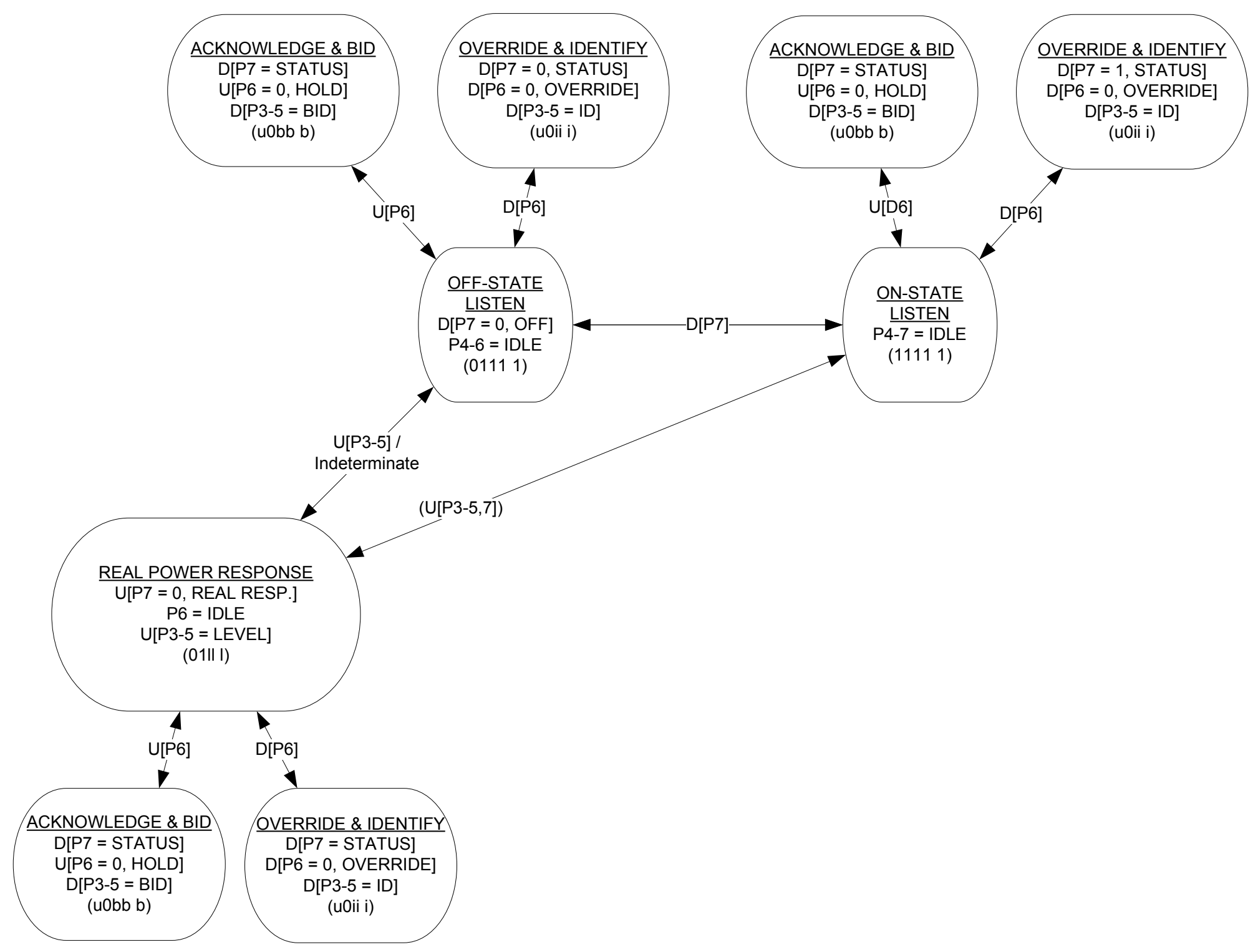

Figure C.3. Load Device State Diagram Three-, Four-, and Five-Pin Implementations 


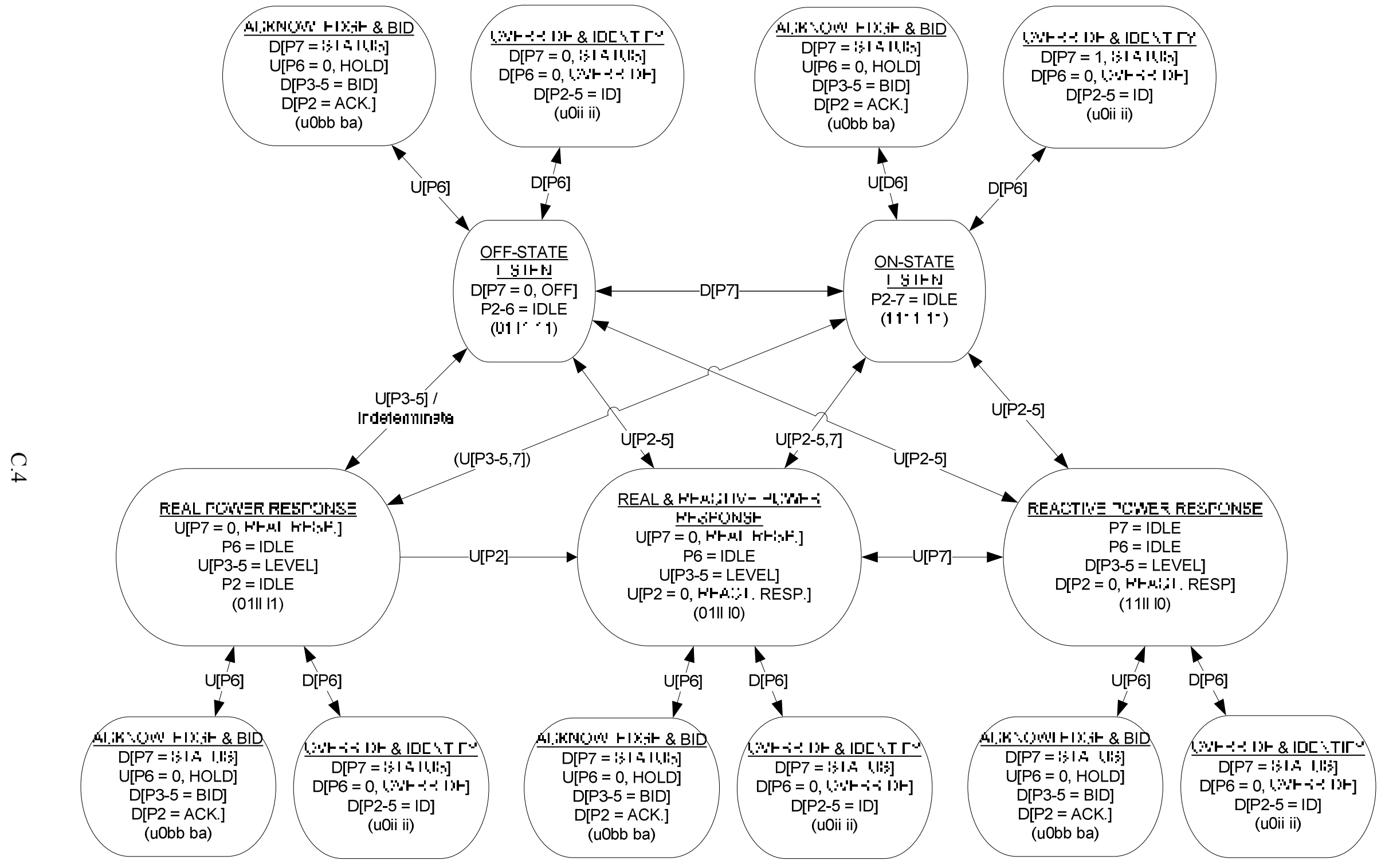

Figure C.4. Load Device State Diagram Six-Pin Implementation 


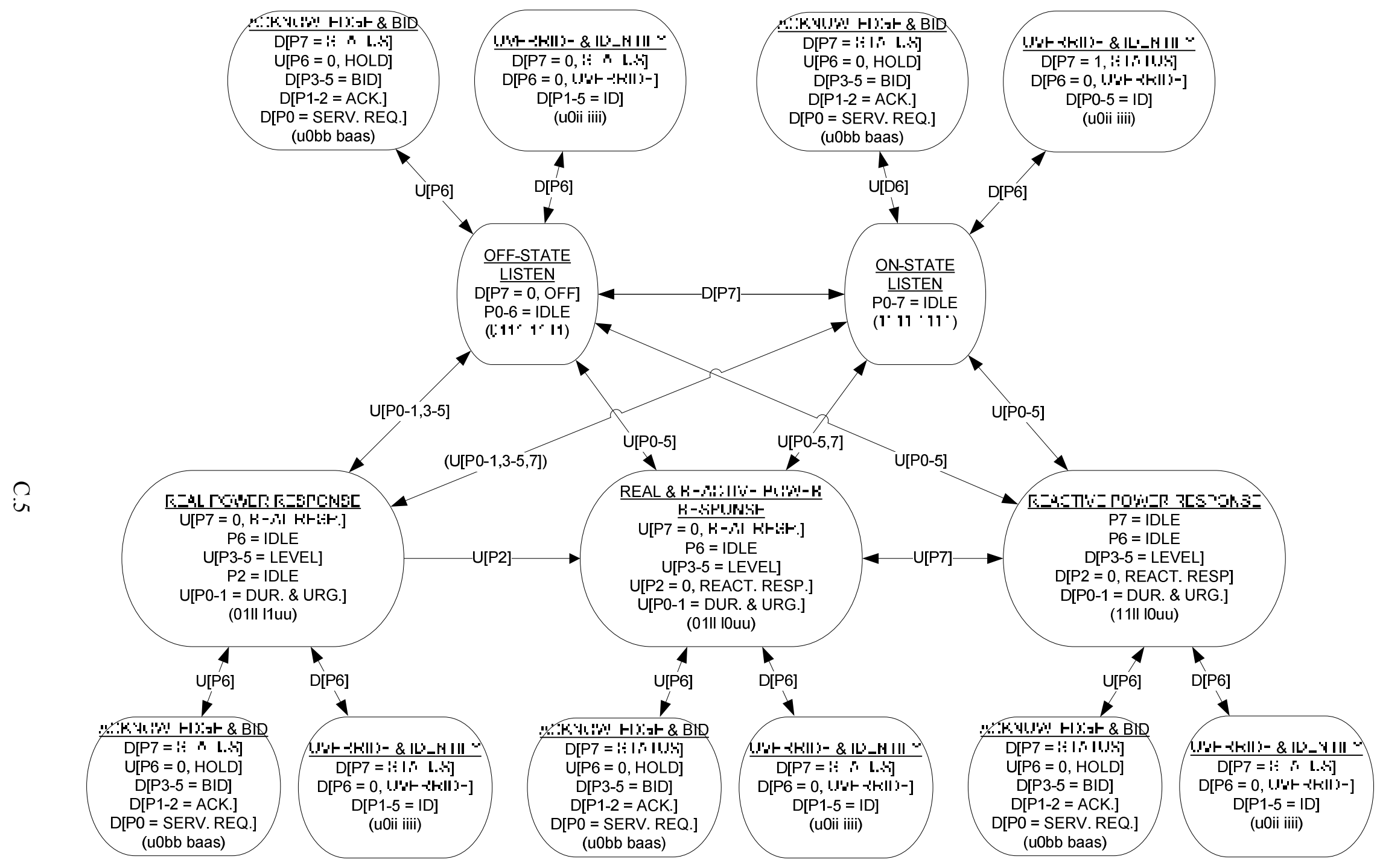

Figure C.5. Load Device State Diagram Seven- and Full Eight-Pin Implementation 

Appendix D

\section{Utility PinBus State Diagrams}





\section{Appendix D: Utility PinBus State Diagrams}

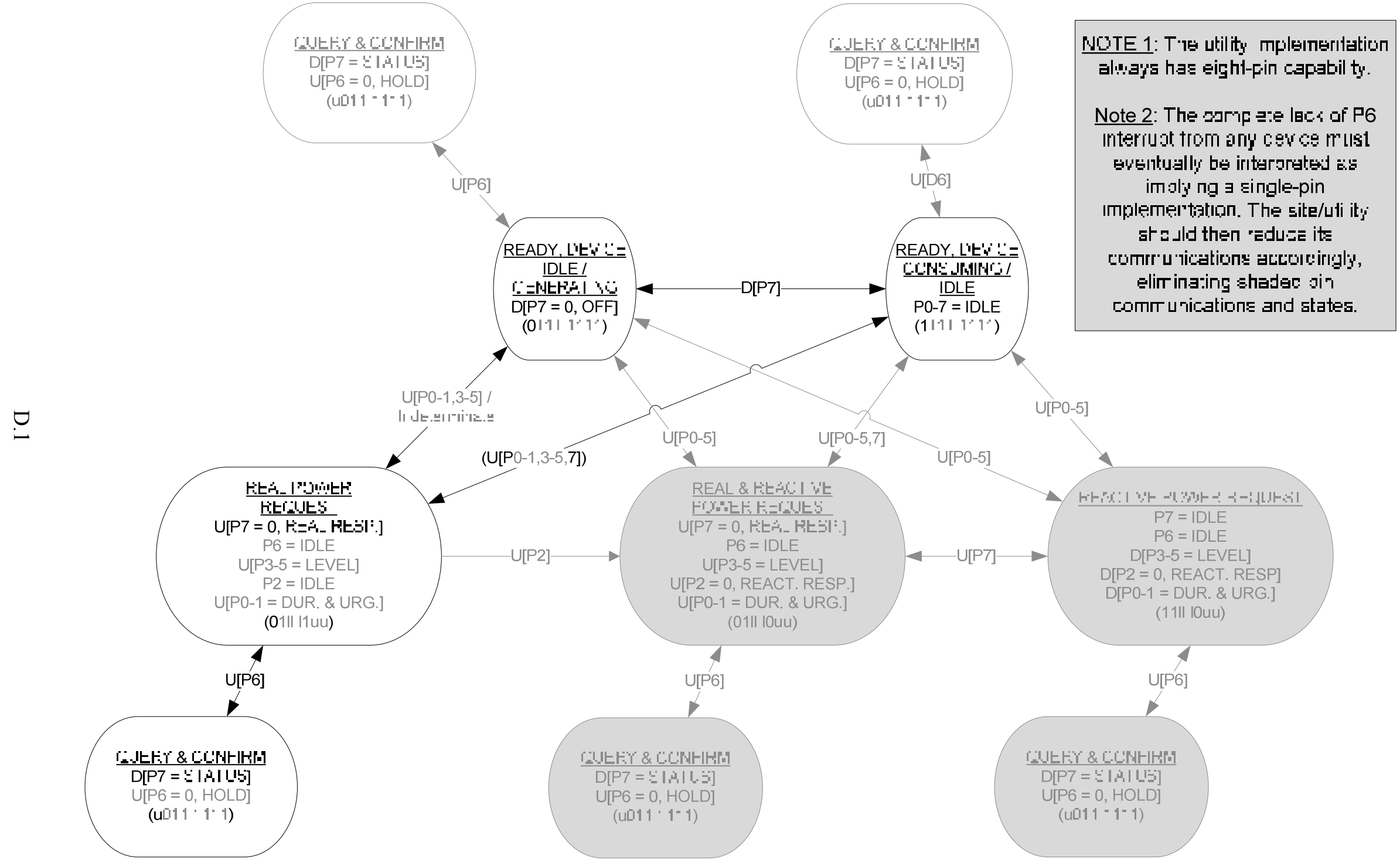

Figure D.1. Utility Control State Diagram One-Pin Implementation 


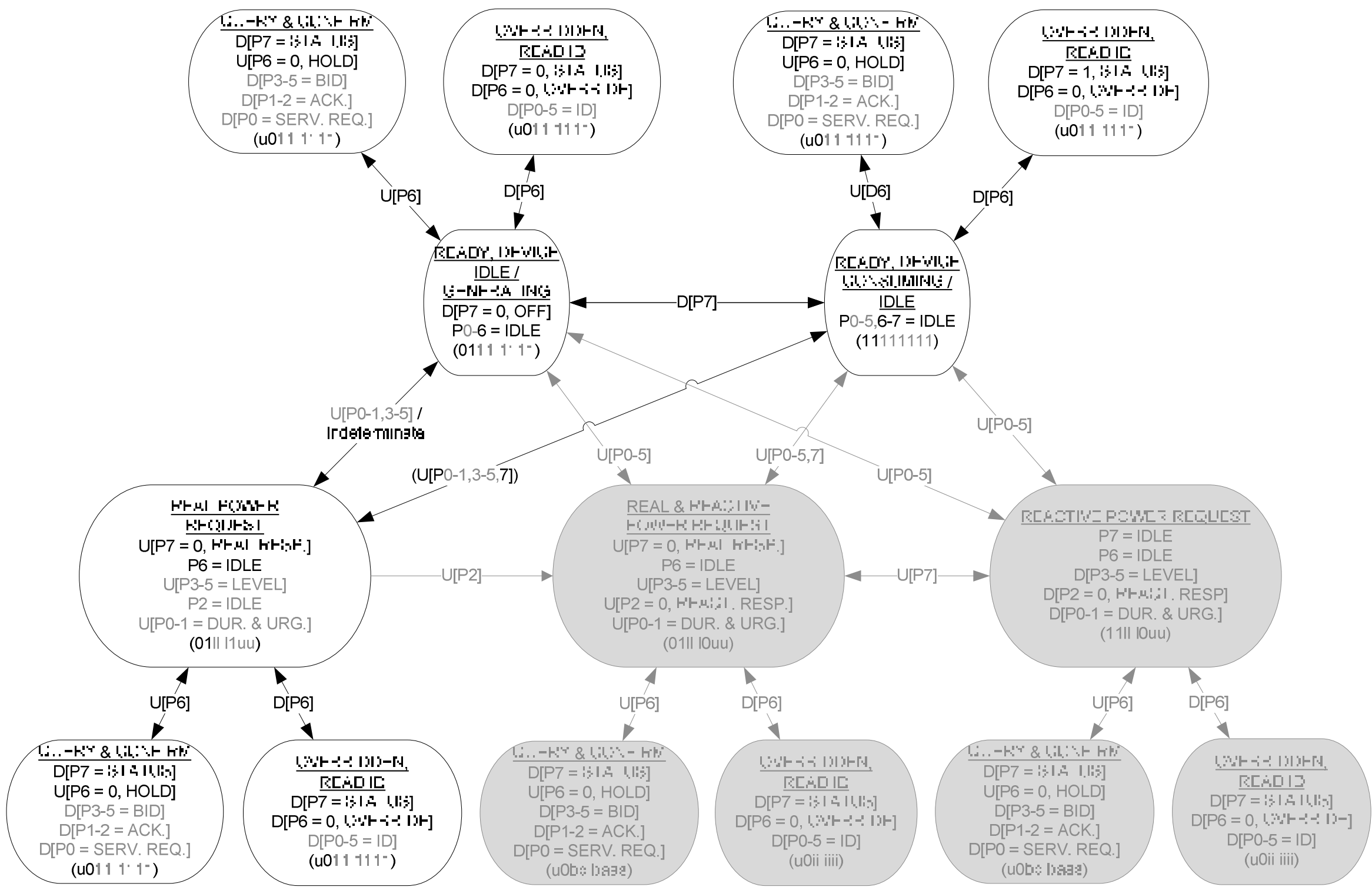

Figure D.2. Utility Control State Diagram Two-Pin Implementation 


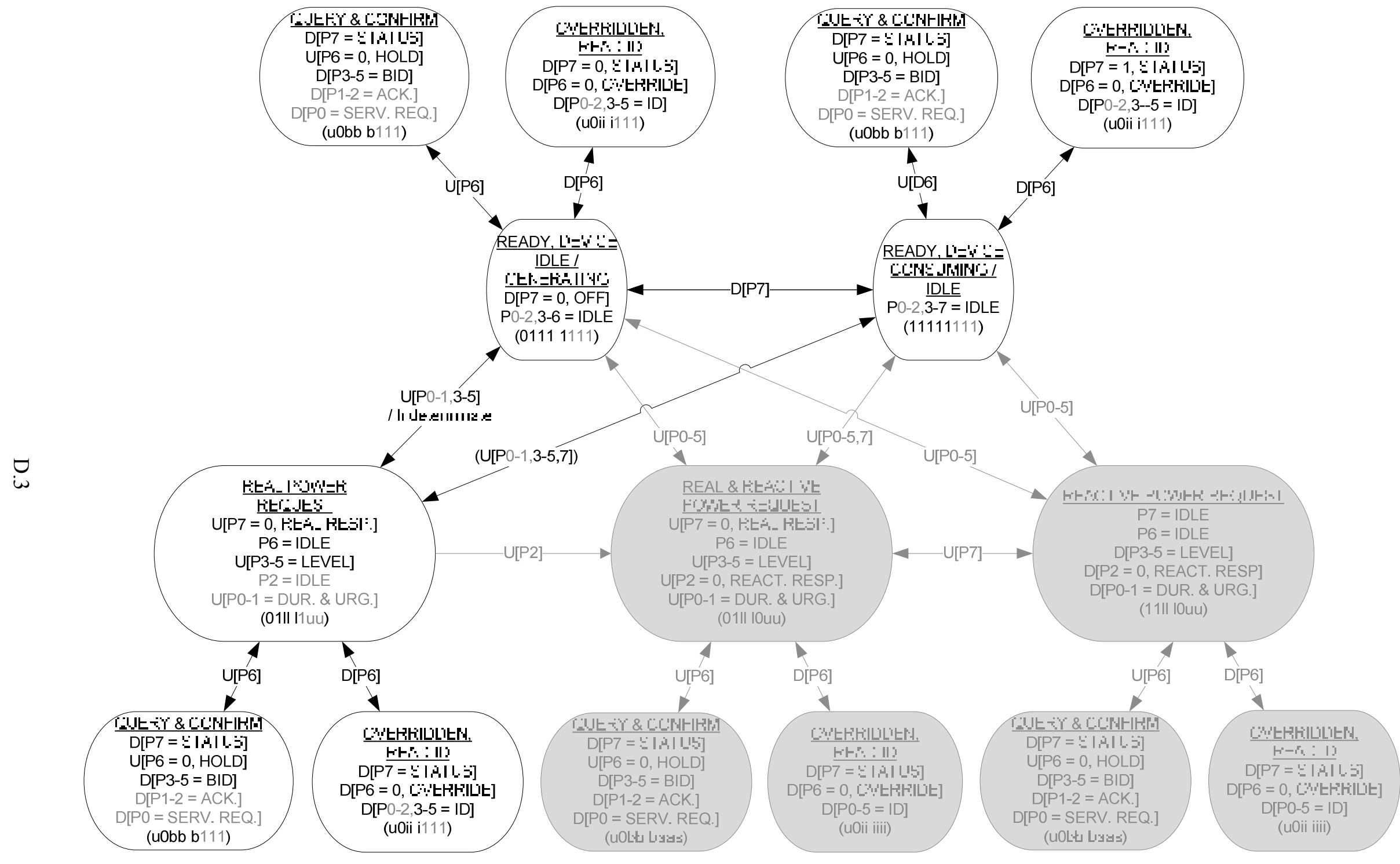

Figure D.3. Utility Control State Diagram Three- Four-, and Five-Pin implementations 


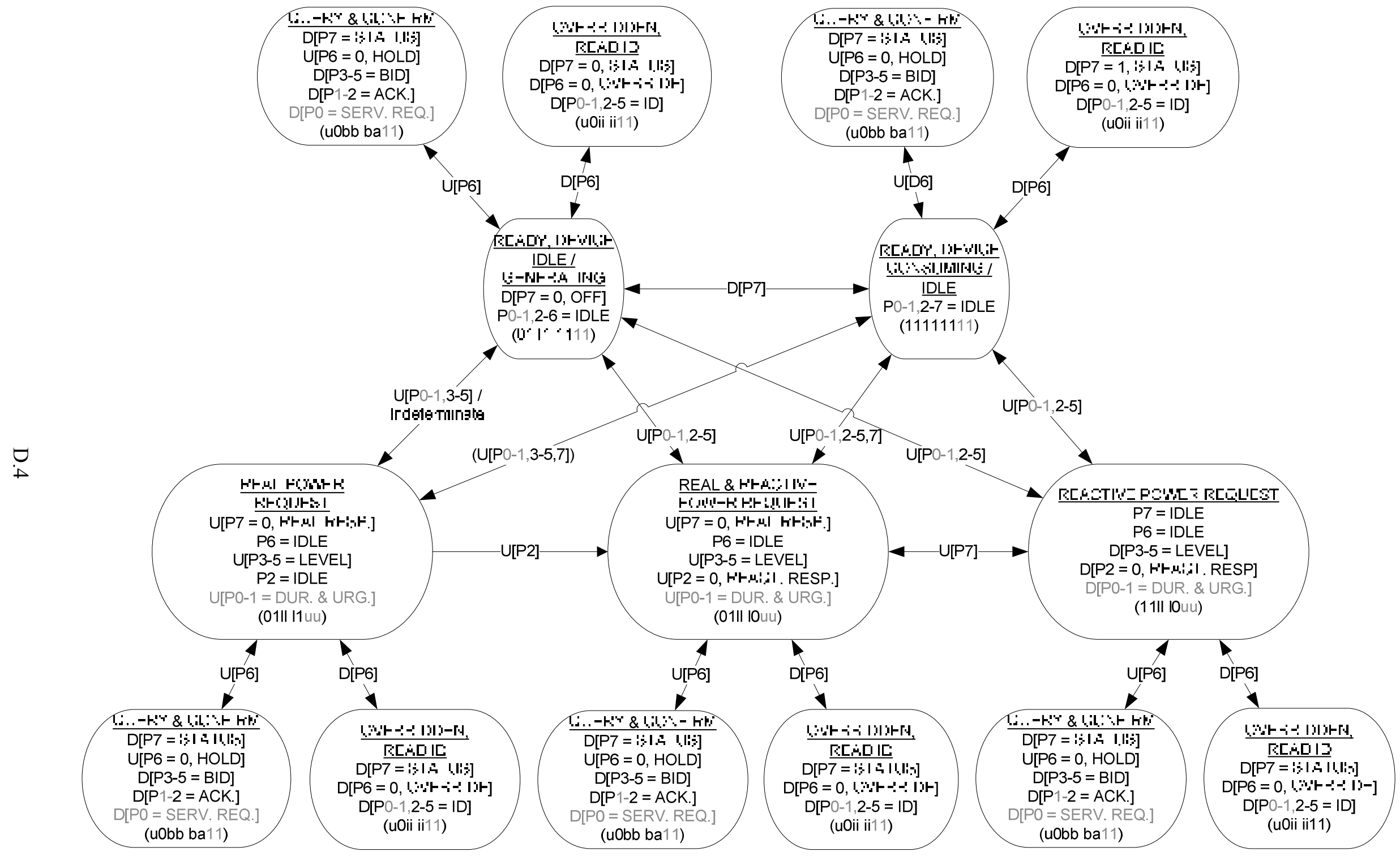

Figure D.4. Utility Control State Diagram Six-Pin Implementation 


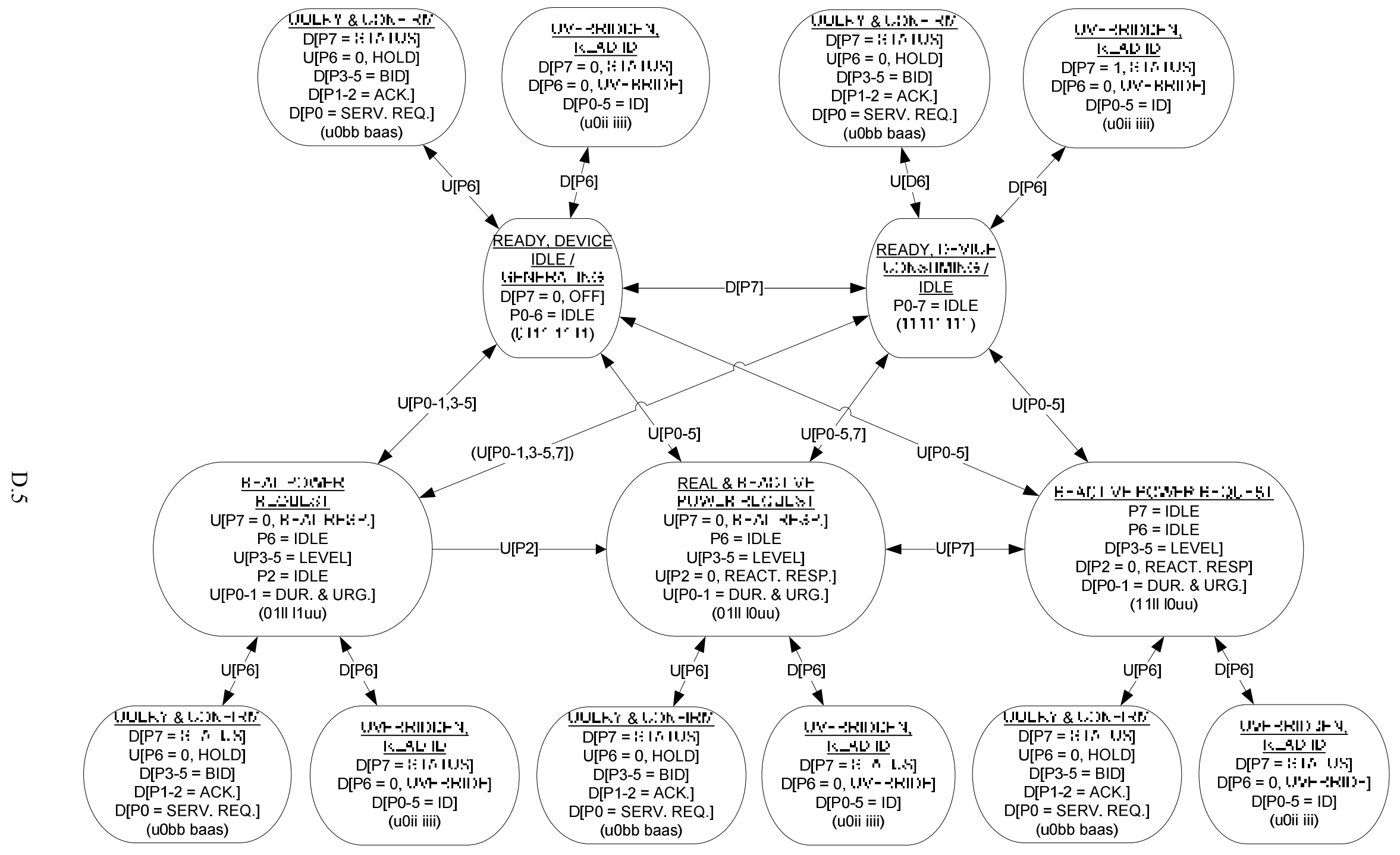

Figure D.5. Utility Control State Diagram Seven- and Full Eight-Pin Implementations 



\section{Appendix E}

\section{Block Diagram - HAN System with PinBus Interfaces}





\section{Appendix E: Block Diagram - HAN System with PinBus Interfaces}

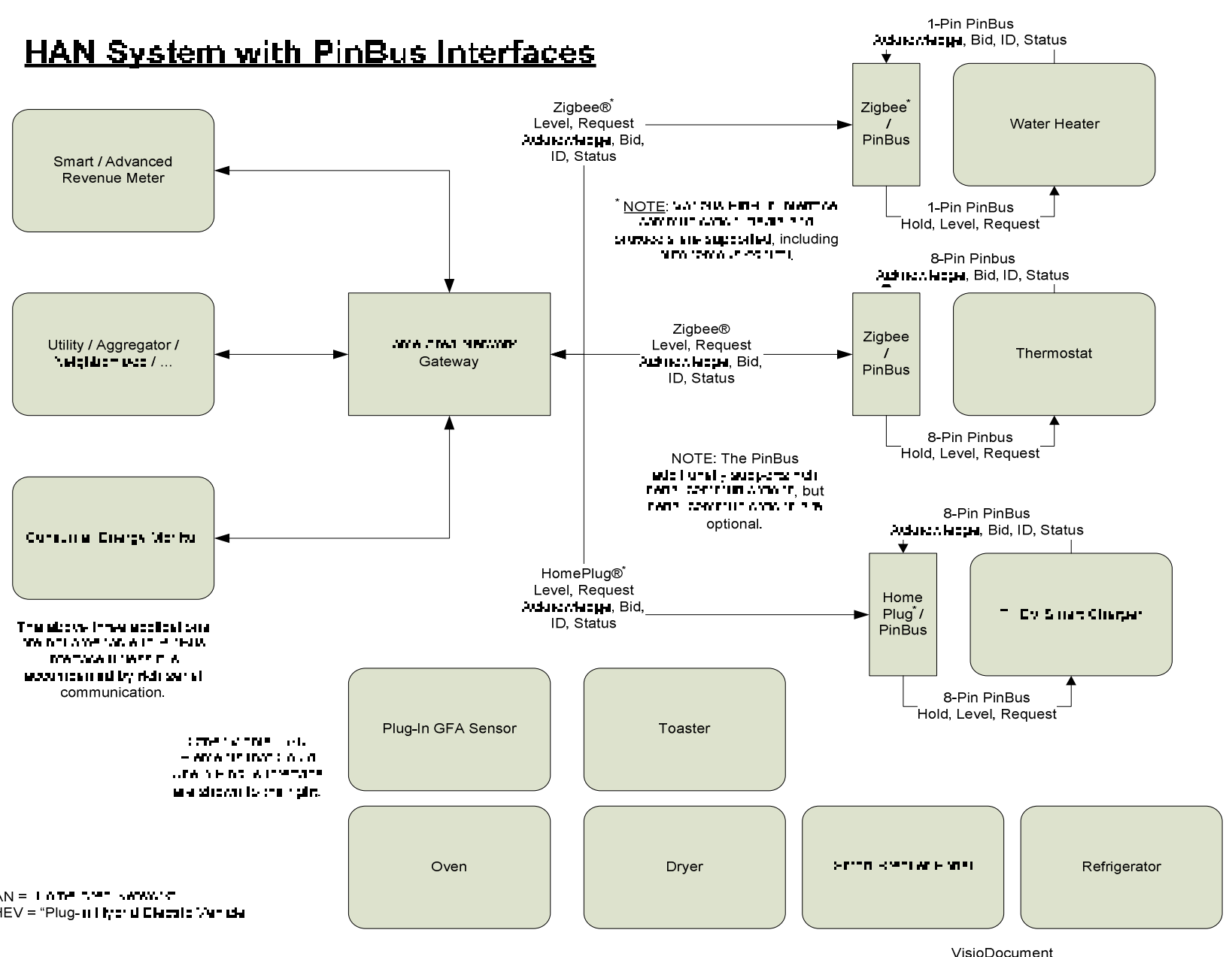

Figure E.1. One Vision of How the PinBus Interface Protocol could Fit into Larger Smart Grid Communication System 

Appendix F Interpretation of PinBus Pin Transitions 



\section{Appendix F: Interpretation of PinBus Pin Transactions}

Table F.1. Exemplary Interpretations of Pin State Transitions

\begin{tabular}{|c|c|c|c|c|c|c|c|}
\hline \multirow[b]{2}{*}{ Prior } & \multirow[b]{2}{*}{$\begin{array}{c}\text { Utility } \\
\text { Request }\end{array}$} & \multirow[b]{2}{*}{$\begin{array}{c}\text { Device } \\
\text { Response }\end{array}$} & \multicolumn{2}{|c|}{ Utility Request } & \multicolumn{2}{|c|}{ Device Response } & \multirow[b]{2}{*}{ Comments: } \\
\hline & & & Demand & Supply & Demand & Supply & \\
\hline \multicolumn{3}{|c|}{ One-pin (pin 7); Utility Requests } & & & & & \\
\hline $\mathrm{x}$ & (1) & - & $\begin{array}{l}\text { Release request to } \\
\text { reduce load }\end{array}$ & $\begin{array}{l}\text { Release request to } \\
\text { increase supply }\end{array}$ & - & - & $\begin{array}{l}\text { Ineffective if device } \\
\text { response has been } \\
\text { overridden. }\end{array}$ \\
\hline $\mathrm{x}$ & 0 & - & Reduce load & Increase supply & - & - & \\
\hline \multicolumn{3}{|c|}{ One-pin (pin 7); Device Responses } & & & & & \\
\hline $\mathrm{x}$ & - & (1) & - & - & $\begin{array}{c}\text { Now } \\
\text { consuming }\end{array}$ & Now idle & $\begin{array}{l}\text { Response } \\
\text { acknowledgment is } \\
\text { not conclusive for } \\
\text { single-pin } \\
\text { implementation. }\end{array}$ \\
\hline $\mathrm{x}$ & - & 0 & - & - & Now idle & $\begin{array}{c}\text { Now } \\
\text { supplying }\end{array}$ & $\begin{array}{l}\text { Even single-pin } \\
\text { implementation can } \\
\text { be monitored for } \\
\text { device on/off } \\
\text { behaviors. }\end{array}$ \\
\hline \multicolumn{3}{|c|}{ Two-pin (pins 6-7); Utility Requests } & & & & & \\
\hline $\mathrm{x} 0$ & $\mathrm{x}(1)$ & - & $\begin{array}{l}\text { Release last request. } \\
\text { Stand by for new } \\
\text { request }\end{array}$ & $\begin{array}{l}\text { Release last request. } \\
\text { Stand by for new } \\
\text { request }\end{array}$ & - & - & $\begin{array}{l}\text { Two-pin } \\
\text { implementation } \\
\text { provides definitive } \\
\text { on/off confirmation. }\end{array}$ \\
\hline $\mathrm{x} 1$ & $\mathrm{x} 0$ & - & $\begin{array}{l}\text { Hold last request and } \\
\text { acknowledge }\end{array}$ & $\begin{array}{l}\text { Hold last request and } \\
\text { acknowledge }\end{array}$ & - & - & \\
\hline \multicolumn{4}{|c|}{ Two-pin (pins 6-7); Device Responses } & & & & \\
\hline $\mathrm{x} 0$ & & $0(1)$ & - & - & $\begin{array}{l}\text { Acknowledge } \\
\text { not consuming }\end{array}$ & $\begin{array}{l}\text { Acknowledge } \\
\text { supplying }\end{array}$ & $\begin{array}{l}\text { Pin } 6 \text { is held low by } \\
\text { utility-side awaiting } \\
\text { acknowledgement on } \\
\text { other pins. Other pins } \\
\text { are used for } \\
\text { acknowledgment. }\end{array}$ \\
\hline $\mathrm{x} 0$ & - & $(1)(1)$ & - & - & $\begin{array}{l}\text { Acknowledge } \\
\text { consuming }\end{array}$ & $\begin{array}{l}\text { Acknowledge } \\
\text { not supplying }\end{array}$ & \\
\hline
\end{tabular}




\begin{tabular}{|c|c|c|c|c|c|c|c|}
\hline \multirow[b]{2}{*}{ Prior } & \multirow[b]{2}{*}{$\begin{array}{c}\text { Utility } \\
\text { Request }\end{array}$} & \multirow[b]{2}{*}{$\begin{array}{c}\text { Device } \\
\text { Response }\end{array}$} & \multicolumn{2}{|c|}{ Utility Request } & \multicolumn{2}{|c|}{ Device Response } & \multirow[b]{2}{*}{ Comments: } \\
\hline & & & Demand & Supply & Demand & Supply & \\
\hline $\mathrm{xx}$ & - & $\mathrm{x} 0$ & - & - & $\begin{array}{l}\text { Not listening. } \\
\text { Overridden. }\end{array}$ & $\begin{array}{l}\text { Not listening. } \\
\text { Overridden. }\end{array}$ & $\begin{array}{l}\text { Pin } 6 \text { is asserted by } \\
\text { device when it is } \\
\text { unavailable, } \\
\text { overridden, or desires } \\
\text { to state its status. }\end{array}$ \\
\hline $\mathrm{xx}$ & & 00 & - & - & $\begin{array}{l}\text { Not listening. } \\
\text { Not } \\
\text { consuming. }\end{array}$ & $\begin{array}{l}\text { Not listening. } \\
\text { Consuming. }\end{array}$ & \\
\hline $\mathrm{xx}$ & & 10 & - & - & $\begin{array}{l}\text { Not listening. } \\
\text { Consuming. }\end{array}$ & $\begin{array}{l}\text { Not listening. } \\
\text { Not } \\
\text { consuming. }\end{array}$ & \\
\hline $\mathrm{xx}$ & & $\mathrm{x}(1)$ & - & - & $\begin{array}{l}\text { Listening. } \\
\text { Ready. }\end{array}$ & $\begin{array}{l}\text { Listening. } \\
\text { Ready. }\end{array}$ & \\
\hline \multicolumn{8}{|c|}{ Three-pin (pins 5-7); Utility Requests } \\
\hline $\mathrm{xxx}$ & 010 & - & $\begin{array}{l}\text { Increase load; price is } \\
\text { low }\end{array}$ & $\begin{array}{l}\text { Reduce supply; price is } \\
\text { low }\end{array}$ & - & - & $\begin{array}{l}\text { Pin } 5 \text { indicates sign of } \\
\text { desired response. Pin } \\
5 \text { can also be } \\
\text { interpreted as relative } \\
\text { price. }\end{array}$ \\
\hline $\mathrm{xxx}$ & 011 & - & $\begin{array}{l}\text { Reduce load; price is } \\
\text { high }\end{array}$ & $\begin{array}{l}\text { Increase supply; price } \\
\text { is high }\end{array}$ & - & - & \\
\hline $\mathrm{x} 1 \mathrm{x}$ & $\mathrm{x} 0 \mathrm{x}$ & - & $\begin{array}{l}\text { Hold last request. Bid } \\
\text { and acknowledge }\end{array}$ & $\begin{array}{l}\text { Hold last request. Bid } \\
\text { and acknowledge }\end{array}$ & - & - & $\begin{array}{l}\text { Utility can request } \\
\text { hold, bid, and } \\
\text { acknowledge using } \\
\text { pin } 6 .\end{array}$ \\
\hline $\mathrm{x} 0 \mathrm{x}$ & $x(1) x$ & - & $\begin{array}{c}\text { Release last request. } \\
\text { Stand by for new } \\
\text { request }\end{array}$ & $\begin{array}{c}\text { Release last request. } \\
\text { Stand by for new } \\
\text { request }\end{array}$ & - & - & \\
\hline \multicolumn{8}{|c|}{ Three-pin (pins 5-7); Device Responses } \\
\hline $\mathrm{x} 0 \mathrm{x}$ & - & $0(1) 0$ & - & - & $\begin{array}{l}\text { Acknowledge } \\
\text { not } \\
\text { consuming, } \\
\text { application is } \\
\text { unsatisfied } \\
\end{array}$ & $\begin{array}{l}\text { Acknowledge } \\
\text { supplying, } \\
\text { generation is } \\
\text { available }\end{array}$ & $\begin{array}{l}\text { Device responds its } \\
\text { status, upon request, } \\
\text { using pins } 5 \text { and } 7 . \\
\text { Pin } 6 \text { is held low by } \\
\text { utility side. }\end{array}$ \\
\hline $\mathrm{x} 0 \mathrm{x}$ & - & $0(1) 1$ & - & - & $\begin{array}{l}\text { Acknowledge } \\
\text { not } \\
\text { consuming, } \\
\text { application is } \\
\text { satisfied }\end{array}$ & $\begin{array}{l}\text { Acknowledge } \\
\text { supplying, } \\
\text { generation is } \\
\text { unavailable }\end{array}$ & \\
\hline
\end{tabular}




\begin{tabular}{|c|c|c|c|c|c|c|c|}
\hline \multirow[b]{2}{*}{ Prior } & \multirow[b]{2}{*}{$\begin{array}{l}\text { Utility } \\
\text { Request }\end{array}$} & \multirow[b]{2}{*}{$\begin{array}{c}\text { Device } \\
\text { Response }\end{array}$} & \multicolumn{2}{|c|}{ Utility Request } & \multicolumn{2}{|c|}{ Device Response } & \multirow[b]{2}{*}{ Comments: } \\
\hline & & & Demand & Supply & Demand & Supply & \\
\hline $\mathrm{x} 0 \mathrm{x}$ & - & $1(1) 1$ & - & - & $\begin{array}{l}\text { Acknowledge } \\
\text { consuming, } \\
\text { application is } \\
\text { satisfied }\end{array}$ & $\begin{array}{c}\text { Acknowledge } \\
\text { not } \\
\text { supplying, } \\
\text { generation is } \\
\text { unavailable }\end{array}$ & \\
\hline $\mathrm{x} 0 \mathrm{x}$ & - & $1(1) 0$ & - & - & $\begin{array}{l}\text { Acknowledge } \\
\text { consuming, } \\
\text { application is } \\
\text { unsatisfied }\end{array}$ & $\begin{array}{c}\text { Acknowledge } \\
\text { not } \\
\text { supplying, } \\
\text { generation is } \\
\text { available } \\
\end{array}$ & \\
\hline \multicolumn{8}{|c|}{ Four- or five-pin (pins 3-7); Utility Requests } \\
\hline $\mathrm{xxxx}-\mathrm{x}$ & 0100-0 & - & $\begin{array}{c}\text { Increase load a little or } \\
\text { none; price is a little } \\
\text { low }\end{array}$ & $\begin{array}{c}\text { Reduce supply a little } \\
\text { or none; price is a little } \\
\text { low }\end{array}$ & - & - & $\begin{array}{l}\text { Pins 3-5 indicate sign } \\
\text { and magnitude of } \\
\text { desired response. }\end{array}$ \\
\hline $\mathrm{xxxx}-\mathrm{x}$ & 0100-1 & - & $\begin{array}{c}\text { Increase load some; } \\
\text { price is somewhat low }\end{array}$ & $\begin{array}{l}\text { Reduce supply some; } \\
\text { price is somewhat low }\end{array}$ & - & - & \\
\hline $\mathrm{xxxx}-\mathrm{x}$ & 0101-0 & - & $\begin{array}{l}\text { Increase load much; } \\
\text { price is very low }\end{array}$ & $\begin{array}{l}\text { Reduce supply much; } \\
\text { price is very low }\end{array}$ & - & - & \\
\hline $\mathrm{xxxx}-\mathrm{x}$ & 0101-1 & - & $\begin{array}{l}\text { Increase load as much } \\
\text { as possible; price is } \\
\text { extremely low }\end{array}$ & $\begin{array}{c}\text { Reduce supply as much } \\
\text { as possible; price is } \\
\text { extremely low }\end{array}$ & - & - & \\
\hline $\mathrm{xxxx}-\mathrm{x}$ & 0110-0 & - & $\begin{array}{c}\text { Reduce load as much as } \\
\text { possible; price is } \\
\text { extremely high }\end{array}$ & $\begin{array}{l}\text { Increase supply as } \\
\text { much as possible; price } \\
\text { is extremely high }\end{array}$ & - & - & \\
\hline $\mathrm{xxxx}-\mathrm{x}$ & 0110-1 & - & $\begin{array}{l}\text { Reduce load much; } \\
\text { price is very high }\end{array}$ & $\begin{array}{l}\text { Increase supply much; } \\
\text { price is very high }\end{array}$ & - & - & \\
\hline $\mathrm{xxxx}-\mathrm{x}$ & 0111-0 & - & $\begin{array}{c}\text { Reduce load more; } \\
\text { price is somewhat high }\end{array}$ & $\begin{array}{l}\text { Increase supply more; } \\
\text { price is somewhat high }\end{array}$ & - & - & \\
\hline $\operatorname{xxxx}-\mathrm{x}$ & 0111-1 & - & $\begin{array}{c}\text { Reduce load a little or } \\
\text { none; price is a little } \\
\text { high }\end{array}$ & $\begin{array}{c}\text { Increase supply a little } \\
\text { or none; price is a little } \\
\text { high }\end{array}$ & - & - & \\
\hline$x 1 x x-x$ & $\mathrm{x} 0 \mathrm{xx}-\mathrm{x}$ & - & $\begin{array}{l}\text { Hold last request and } \\
\text { acknowledge }\end{array}$ & $\begin{array}{l}\text { Hold last request and } \\
\text { acknowledge }\end{array}$ & - & - & $\begin{array}{l}\text { Utility can still } \\
\text { request hold and } \\
\text { acknowledge using } \\
\text { pin } 6 .\end{array}$ \\
\hline$x 0 x x-x$ & $x(1) x x-x$ & - & $\begin{array}{l}\text { Release last request. } \\
\text { Stand by for new } \\
\text { request }\end{array}$ & $\begin{array}{c}\text { Release last request. } \\
\text { Stand by for new } \\
\text { request }\end{array}$ & - & - & \\
\hline
\end{tabular}




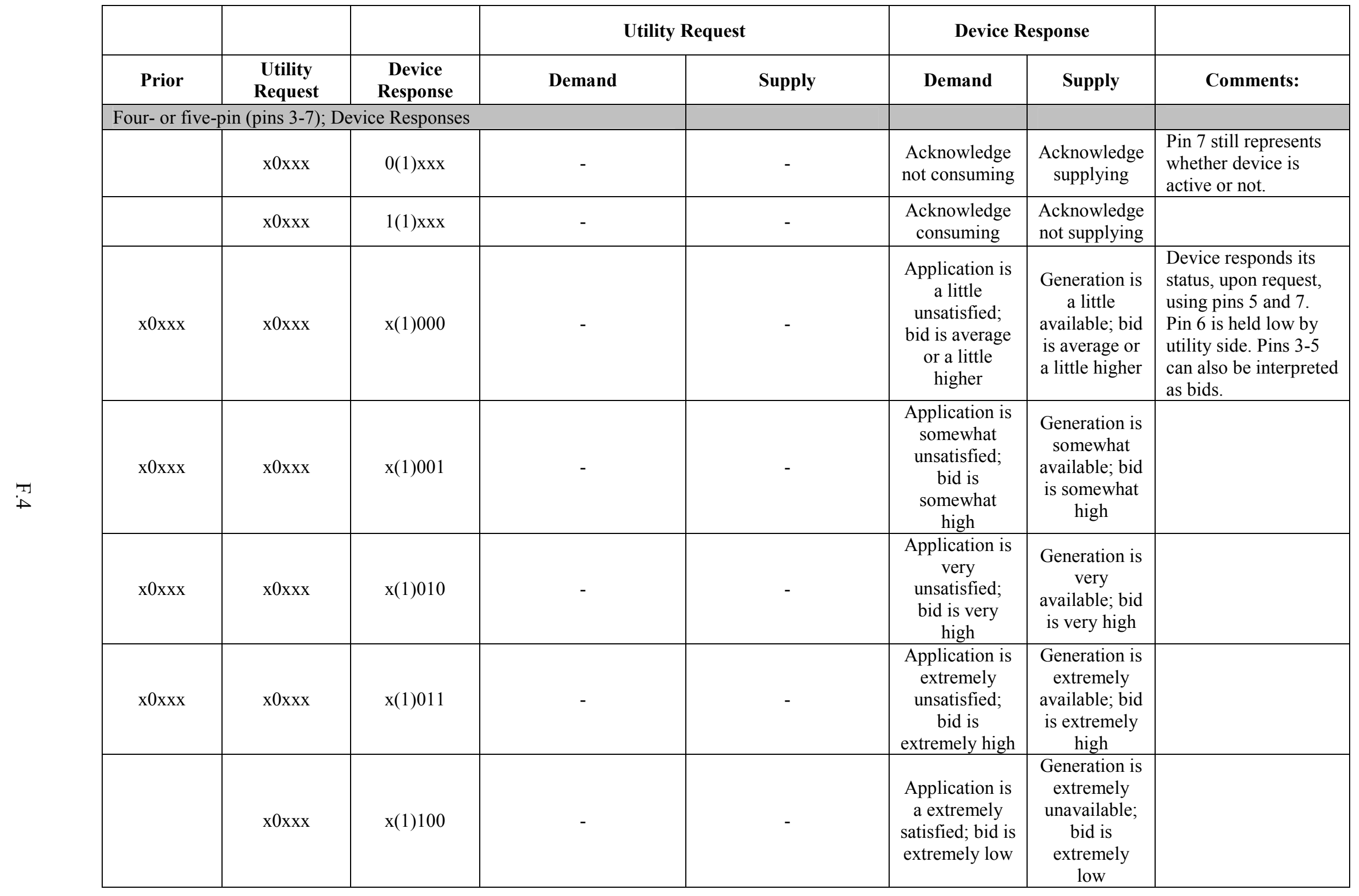




\begin{tabular}{|c|c|c|c|c|c|c|c|}
\hline \multirow[b]{2}{*}{ Prior } & \multirow[b]{2}{*}{$\begin{array}{c}\text { Utility } \\
\text { Request }\end{array}$} & \multirow[b]{2}{*}{$\begin{array}{c}\text { Device } \\
\text { Response }\end{array}$} & \multicolumn{2}{|c|}{ Utility Request } & \multicolumn{2}{|c|}{ Device Response } & \multirow[b]{2}{*}{ Comments: } \\
\hline & & & Demand & Supply & Demand & Supply & \\
\hline & $\mathrm{x} 0 \mathrm{xxx}$ & $\mathrm{x}(1) 101$ & - & - & $\begin{array}{l}\text { Application is } \\
\text { very satisfied; } \\
\text { bid is very low }\end{array}$ & $\begin{array}{c}\text { Generation is } \\
\text { very } \\
\text { unavailable; } \\
\text { bid is very } \\
\text { low }\end{array}$ & \\
\hline & $\mathrm{x} 0 \mathrm{xxx}$ & $\mathrm{x}(1) 110$ & - & - & $\begin{array}{l}\text { Application is } \\
\text { somewhat } \\
\text { satisfied; bid is } \\
\text { somewhat low }\end{array}$ & $\begin{array}{c}\text { Generation is } \\
\text { somewhat } \\
\text { unavailable; } \\
\text { bid is } \\
\text { somewhat } \\
\text { low }\end{array}$ & \\
\hline & $\mathrm{x} 0 \mathrm{xxx}$ & $\mathrm{x}(1) 111$ & - & - & $\begin{array}{l}\text { Application is } \\
\text { a little } \\
\text { satisfied; bid is } \\
\text { average or a } \\
\text { little lower }\end{array}$ & $\begin{array}{l}\text { Generation is } \\
\text { a little } \\
\text { unavailable; } \\
\text { bid is average } \\
\text { or a little } \\
\text { lower }\end{array}$ & \\
\hline \multicolumn{8}{|c|}{ Six-pin (pins 2-7); Utility Requests } \\
\hline $\mathrm{xxxxxx}$ & $\mathrm{x} 11 \mathrm{xx} 0$ & & Reduce reactive load & $\begin{array}{l}\text { Increase reactive } \\
\text { generation }\end{array}$ & - & - & $\begin{array}{l}\text { Pin } 2 \text { requests } \\
\text { changes in reactive } \\
\text { power. Pins } 3-5 \\
\text { modify the sign and } \\
\text { magnitude of request } \\
\text { as was shown above } \\
\text { for real power } \\
\text { requests. }\end{array}$ \\
\hline $\operatorname{xxxxxx}$ & $\mathrm{x} 10 \mathrm{xx} 0$ & & Increase reactive load & $\begin{array}{c}\text { Reduce reactive } \\
\text { generation }\end{array}$ & - & - & \\
\hline $\operatorname{xxxxxx}$ & $011 \times x 0$ & & $\begin{array}{l}\text { Reduce both real and } \\
\text { reactive load; price is } \\
\text { high }\end{array}$ & $\begin{array}{c}\text { Increase reactive } \\
\text { generation; price is } \\
\text { high }\end{array}$ & - & - & $\begin{array}{l}\text { The control of real } \\
\text { and reactive power is } \\
\text { not independent in } \\
\text { this scheme. Both } \\
\text { should be asserted } \\
\text { only when the need is } \\
\text { similar for both. }\end{array}$ \\
\hline $\operatorname{xxxxxx}$ & 010xx0 & & $\begin{array}{l}\text { Increase both real and } \\
\text { reactive load; price is } \\
\text { low }\end{array}$ & $\begin{array}{c}\text { Reduce reactive } \\
\text { generation; price is low }\end{array}$ & - & - & \\
\hline
\end{tabular}




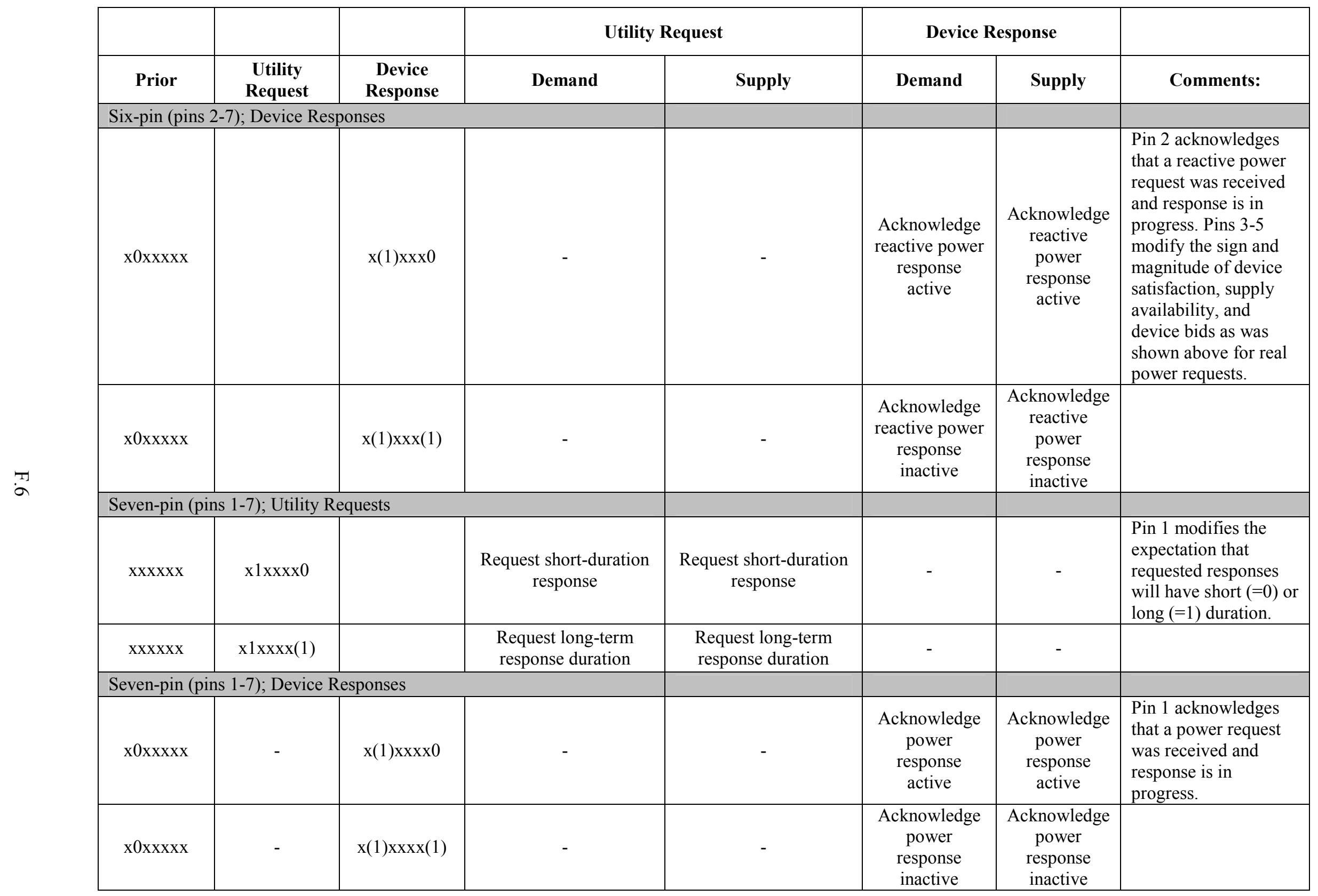




\begin{tabular}{|c|c|c|c|c|c|c|c|}
\hline \multirow[b]{2}{*}{ Prior } & \multirow[b]{2}{*}{$\begin{array}{c}\text { Utility } \\
\text { Request }\end{array}$} & \multirow[b]{2}{*}{$\begin{array}{c}\text { Device } \\
\text { Response }\end{array}$} & \multicolumn{2}{|c|}{ Utility Request } & \multicolumn{2}{|c|}{ Device Response } & \multirow[b]{2}{*}{ Comments: } \\
\hline & & & Demand & Supply & Demand & Supply & \\
\hline \multicolumn{8}{|c|}{ Full eight-pin (pins 0-7); Utility Requests } \\
\hline xxxxxxxx & $\mathrm{x} 1 \mathrm{xxxxx0}$ & - & This request is urgent & This request is urgent & - & - & $\begin{array}{l}\text { Pin } 0 \text { modifies the } \\
\text { expectation that } \\
\text { requested responses } \\
\text { have high }(=0) \text { or low } \\
(=1) \text { urgency. }\end{array}$ \\
\hline xxxxxxxx & $\mathrm{x} 1 \mathrm{xxxxx1}$ & - & $\begin{array}{c}\text { This request is not } \\
\text { urgent }\end{array}$ & $\begin{array}{l}\text { This request is not } \\
\text { urgent }\end{array}$ & - & - & \\
\hline \multicolumn{8}{|c|}{ Full eight--pin (pins 0-7); Device Responses } \\
\hline $\mathrm{x} 0 \mathrm{xxxxxx}$ & - & $\mathrm{x}(1) \mathrm{xxxxx0}$ & - & - & $\begin{array}{l}\text { Device needs } \\
\text { attention or } \\
\text { service }\end{array}$ & $\begin{array}{c}\text { Device needs } \\
\text { attention or } \\
\text { service }\end{array}$ & $\begin{array}{l}\text { Pin } 0 \text { allows device to } \\
\text { request service }(=0) \text { or } \\
\text { state that it is ok }(=1) \text {. }\end{array}$ \\
\hline x0xxxxxx & - & $\mathrm{x}(1) \operatorname{xxxxx}(1)$ & - & - & $\begin{array}{c}\text { Device is ok } \\
\text { (default) }\end{array}$ & $\begin{array}{c}\text { Device is ok } \\
\text { (default) }\end{array}$ & \\
\hline $\mathrm{x} 1 \mathrm{xxxxxx}$ & & x0(zzzzzz) & - & - & $\begin{array}{l}\text { Not listening. } \\
\text { Overridden. } \\
\text { Here's device } \\
\text { type. }\end{array}$ & $\begin{array}{c}\text { Not listening. } \\
\text { Overridden. } \\
\text { Here's device } \\
\text { type. }\end{array}$ & $\begin{array}{l}\text { ID }= \\
\text { \$3: Simple one- or } \\
\text { two-pin interface } \\
\text { \$1F: Simple three-pin } \\
\text { interface } \\
\text { \$F: Simple four-pin } \\
\text { interface* } \\
\text { \$7: Simple five-pin } \\
\text { interface**** } \\
\text { \$3: Simple six-pin } \\
\text { interface******** } \\
\text { \$1: Simple seven- or } \\
\text { eight-pin interface* } \\
* * * * * * * * * * \\
\text { ID=odd means OK; } \\
\text { even means service } \\
\text { requested }\end{array}$ \\
\hline
\end{tabular}




\begin{tabular}{|c|c|c|c|c|c|c|c|}
\hline \multirow[b]{2}{*}{ Prior } & \multirow[b]{2}{*}{$\begin{array}{c}\text { Utility } \\
\text { Request }\end{array}$} & \multirow[b]{2}{*}{$\begin{array}{c}\text { Device } \\
\text { Response }\end{array}$} & \multicolumn{2}{|c|}{ Utility Request } & \multicolumn{2}{|c|}{ Device Response } & \multirow[b]{2}{*}{ Comments: } \\
\hline & & & Demand & Supply & Demand & Supply & \\
\hline & & & & & & & $\begin{array}{l}* \text { AND with } \$ 20 \text { to } \\
\text { identify } \\
\text { corresponding supply } \\
* * \text { AND with } \$ 10 \text { for } \\
\text { bid- and price- } \\
\text { responsive device } \\
* * * \text { AND with } \$ 8 \text { for } \\
\text { device having both } \\
\text { real and reactive } \\
\text { responses } \\
* * * * \text { AND with } \$ 4 \\
\text { for device having } \\
\text { autonomous responses }\end{array}$ \\
\hline
\end{tabular}


Appendix G

Table of Grid Responses of Interest 



\section{Appendix G: Table of Grid Responses of Interest}

Table G.1. Responses Available from Various Appliance Types

\begin{tabular}{|c|c|c|c|c|c|c|c|c|c|c|}
\hline Response & $\underline{\mathbf{S} / \mathbf{C} / \mathbf{A}^{(1)}}$ & Description & Value $^{(3)}$ & Alternative & $\underline{\text { Cause }}$ & Duration & Urgency & Frequency & $\underline{\text { Response }}^{\text {Desired }}$ & $\frac{\text { Example }^{(4)}}{\text { Code }^{(4)}}$ \\
\hline $\begin{array}{l}\text { Under- } \\
\text { frequency }\end{array}$ & $\mathrm{A},(\mathrm{C})$ & $\begin{array}{l}\text { Grid electrical } \\
\text { frequency falls } \\
\text { below an } \\
\text { accepted } \\
\text { operating } \\
\text { range. }\end{array}$ & Medium & $\begin{array}{l}\text { Some } \\
\text { substations } \\
\text { now turn off } \\
\text { entire } \\
\text { customer } \\
\text { circuits } \\
\text { starting at } \\
\text { about } 59.8 \mathrm{~Hz} \\
\text { or lower. } \\
\text { Spinning } \\
\text { reserves are } \\
\text { called into } \\
\text { play but may } \\
\text { be too slow to } \\
\text { respond. }\end{array}$ & $\begin{array}{l}\text { Unscheduled } \\
\text { loss of } \\
\text { generation. }\end{array}$ & $\begin{array}{l}1 \mathrm{~s} \text { to } 10 \\
\text { minutes }\end{array}$ & $<1 \mathrm{~s}$ & Infrequent & $\begin{array}{l}\text { Reduce real } \\
\text { power } \\
\text { electrical load. }\end{array}$ & $\begin{array}{l}1010- \\
0010\end{array}$ \\
\hline $\begin{array}{l}\text { Over- } \\
\text { frequency }\end{array}$ & $\mathrm{A},(\mathrm{C})$ & $\begin{array}{l}\text { Grid electrical } \\
\text { frequency } \\
\text { exceeds } \\
\text { accepted } \\
\text { operating } \\
\text { range. }\end{array}$ & Medium & $\begin{array}{l}\text { Some } \\
\text { generators } \\
\text { trip off for } \\
\text { over- } \\
\text { frequency. } \\
\text { Reduction in } \\
\text { generation is } \\
\text { desirable but } \\
\text { may be too } \\
\text { slow. }\end{array}$ & $\begin{array}{l}\text { Overshoot } \\
\text { during fault } \\
\text { recovery. } \\
\text { Excess } \\
\text { generation. }\end{array}$ & $\begin{array}{l}1 \mathrm{~s} \text { to about } \\
30 \mathrm{~s}\end{array}$ & $<1 \mathrm{~s}$ & Infrequent & $\begin{array}{l}\text { Increase real- } \\
\text { power } \\
\text { electrical load. }\end{array}$ & $\begin{array}{l}1010- \\
0110\end{array}$ \\
\hline
\end{tabular}




\begin{tabular}{|c|c|c|c|c|c|c|c|c|c|c|}
\hline$\underline{\text { Response }}$ & $\underline{\mathbf{S} / \mathbf{C} / \mathbf{A}^{(1)}}$ & $\underline{\text { Description }}$ & Value $^{(3)}$ & $\underline{\text { Alternative }}$ & $\underline{\text { Cause }}$ & Duration & Urgency & $\underline{\text { Frequency }}$ & $\underset{\text { Response }^{(2)}}{\text { Desired }}$ & $\frac{\text { Example }^{(4)}}{\text { Code }^{(4)}}$ \\
\hline $\begin{array}{l}\text { Under- } \\
\text { voltage }\end{array}$ & $\mathrm{A},(\mathrm{C})$ & $\begin{array}{l}\text { Circuit voltage } \\
\text { falls below } \\
\text { accepted } \\
\text { operating } \\
\text { range. }\end{array}$ & $\begin{array}{l}\text { Medium - } \\
\text { High (?) }\end{array}$ & $\begin{array}{l}\text { Prolonged } \\
\left(30 s^{+}\right) \\
\text {natural } \\
\text { recovery or } \\
\text { cascading } \\
\text { voltage } \\
\text { instability. } \\
\text { Apply active } \\
\text { or passive } \\
\text { voltage } \\
\text { support. }\end{array}$ & $\begin{array}{l}\text { Faults on } \\
\text { circuits that } \\
\text { are heavily } \\
\text { loaded by } \\
\text { compressor } \\
\text { loads. }\end{array}$ & $\begin{array}{l}0.1 \mathrm{~s}- \\
\text { about } 30 \\
\text { seconds }\end{array}$ & $<1 \mathrm{~s}$ & $\begin{array}{l}\text { Becoming } \\
\text { more } \\
\text { frequent } \\
\text { with } \\
\text { popularity } \\
\text { of air } \\
\text { conditioning } \\
\text { load }\end{array}$ & $\begin{array}{l}\text { Reduce } \\
\text { electrical } \\
\text { loads- } \\
\text { especially } \\
\text { inductive } \\
\text { stalled } \\
\text { compressor } \\
\text { loads. Add } \\
\text { capacitive } \\
\text { load support. }\end{array}$ & $\begin{array}{l}1010- \\
1010\end{array}$ \\
\hline $\begin{array}{l}\text { Over- } \\
\text { voltage }\end{array}$ & $\mathrm{A},(\mathrm{C})$ & $\begin{array}{l}\text { Circuit voltage } \\
\text { exceeds } \\
\text { accepted } \\
\text { operating } \\
\text { range. }\end{array}$ & $\begin{array}{l}\text { Medium - } \\
\text { High (?) }\end{array}$ & $\begin{array}{l}\text { Remove } \\
\text { active and } \\
\text { passive } \\
\text { voltage } \\
\text { support. }\end{array}$ & $\begin{array}{l}\text { Overshoot } \\
\text { during fault } \\
\text { recovery. } \\
\text { Uncoordinated } \\
\text { responses. }\end{array}$ & $1-15 \mathrm{~s}$ & $<1 \mathrm{~s}$ & $\begin{array}{l}\text { Commonly } \\
\text { paired with } \\
\text { under- } \\
\text { voltage } \\
\text { events. }\end{array}$ & $\begin{array}{l}\text { Increase } \\
\text { load- } \\
\text { especially } \\
\text { inductive load. } \\
\text { Remove } \\
\text { capacitive } \\
\text { load. }\end{array}$ & $\begin{array}{l}1010- \\
1110\end{array}$ \\
\hline $\begin{array}{l}\text { Up } \\
\text { regulation }\end{array}$ & $\mathrm{C}, \mathrm{A}$ & $\begin{array}{l}\text { A service } \\
\text { balancing the } \\
\text { match of load } \\
\text { and generation } \\
\text { by increasing } \\
\text { generation or } \\
\text { reducing load. }\end{array}$ & $\begin{array}{l}\text { High. } \\
\text { Value } \\
\text { tends to } \\
\text { increase } \\
\text { with } \\
\text { speed of } \\
\text { response } \\
\text { and } \\
\text { power. }\end{array}$ & $\begin{array}{l}\text { Presently } \\
\text { provided by a } \\
\text { sampling of } \\
\text { generation } \\
\text { supply. } \\
\text { Generator } \\
\text { control and } \\
\text { supply } \\
\text { response to } \\
\text { Area Control } \\
\text { Error. }\end{array}$ & $\begin{array}{l}\text { Necessary to } \\
\text { match } \\
\text { generation and } \\
\text { load at short } \\
\text { intervals. } \\
\text { Fixes errant } \\
\text { supply } \\
\text { schedules. } \\
\text { Unpredictable } \\
\text { loads and } \\
\text { renewable } \\
\text { resources. }\end{array}$ & Continuous. & $\begin{array}{l}4 \mathrm{~s} \\
\text { intervals }\end{array}$ & $\mathrm{n} / \mathrm{a}$ & $\begin{array}{l}\text { Reduction of } \\
\text { real electrical } \\
\text { load in } \\
\text { proportion to } \\
\text { decrease in } \\
\text { communicated } \\
\text { signal or } \\
\text { frequency. }\end{array}$ & $\begin{array}{l}1111- \\
0000 \\
\text { through } \\
1111- \\
0010\end{array}$ \\
\hline
\end{tabular}




\begin{tabular}{|c|c|c|c|c|c|c|c|c|c|c|}
\hline$\underline{\text { Response }}$ & $\underline{\mathbf{S} / \mathbf{C} / \mathbf{A}^{(1)}}$ & Description & Value $^{(3)}$ & Alternative & Cause & Duration & Urgency & Frequency & $\underset{\text { Response }^{(2)}}{\text { Desired }^{2}}$ & 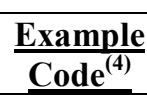 \\
\hline $\begin{array}{l}\text { Down } \\
\text { regulation }\end{array}$ & $\mathrm{C}, \mathrm{A}$ & $\begin{array}{l}\text { A service } \\
\text { balancing the } \\
\text { match of load } \\
\text { and generation } \\
\text { by increasing } \\
\text { load or } \\
\text { reducing } \\
\text { generation. }\end{array}$ & $\begin{array}{l}\text { High. } \\
\text { Value } \\
\text { tends to } \\
\text { increase } \\
\text { with } \\
\text { speed of } \\
\text { response } \\
\text { and } \\
\text { power. }\end{array}$ & $\begin{array}{l}\text { Presently } \\
\text { provided by a } \\
\text { sampling of } \\
\text { generation } \\
\text { supply. } \\
\text { Generator } \\
\text { control and } \\
\text { Area Control } \\
\text { Error. }\end{array}$ & $\begin{array}{l}\text { Necessary to } \\
\text { match } \\
\text { generation and } \\
\text { load at short } \\
\text { intervals. } \\
\text { Fixes errant } \\
\text { supply } \\
\text { schedules. } \\
\text { Unpredictable } \\
\text { loads and } \\
\text { renewable } \\
\text { resources. }\end{array}$ & Continuous. & $\begin{array}{l}\sim 4 \mathrm{~s} \\
\text { intervals }\end{array}$ & $\mathrm{n} / \mathrm{a}$ & $\begin{array}{l}\text { Increase of } \\
\text { real electrical } \\
\text { load in } \\
\text { proportion to } \\
\text { increase in } \\
\text { communicated } \\
\text { signal or } \\
\text { frequency. }\end{array}$ & $\begin{array}{l}\overline{111-} \\
0100 \\
\text { through } \\
1111- \\
0110\end{array}$ \\
\hline $\begin{array}{l}\text { Peak } \\
\text { management }\end{array}$ & $\begin{array}{l}\text { S, C, } \\
\text { (A) }\end{array}$ & $\begin{array}{l}\text { A generic term } \\
\text { used for those } \\
\text { methods which } \\
\text { reduce or defer } \\
\text { peak load. }\end{array}$ & & & & & & & & \\
\hline $\begin{array}{l}\text { On-/off- } \\
\text { peak }\end{array}$ & $\begin{array}{l}\text { S, C, } \\
\text { (A) }\end{array}$ & $\begin{array}{l}\text { Means for } \\
\text { removing } \\
\text { electric load } \\
\text { from peak } \\
\text { periods or } \\
\text { encouraging } \\
\text { electric load } \\
\text { off-peak. } \\
\text { Usually } \\
\text { scheduled at } \\
\text { least the day } \\
\text { ahead. May be } \\
\text { communicated. }\end{array}$ & $\begin{array}{l}\text { Moderate, } \\
\text { often built } \\
\text { into rate } \\
\text { tariffs. }\end{array}$ & $\begin{array}{l}\text { Timers. } \\
\text { Aggregator } \\
\text { devices } \\
\text { respond to } \\
\text { this need for } \\
\text { water heaters, } \\
\text { pool pumps, } \\
\text { and } \\
\text { thermostatic } \\
\text { loads. } \\
\text { Unmitigated } \\
\text { peak results } \\
\text { in overloaded } \\
\text { system and } \\
\text { equipment } \\
\text { failures. }\end{array}$ & $\begin{array}{l}\text { Crude means } \\
\text { of planning for } \\
\text { and mitigating } \\
\text { peak seasonal } \\
\text { and daily } \\
\text { loads. }\end{array}$ & $\begin{array}{l}\text { Applied } \\
\text { about twice } \\
\text { per day for } \\
1-4 \text { hours } \\
\text { on-peak. }\end{array}$ & $\begin{array}{l}<\sim 10 \\
\text { minutes } \\
\text { is ok. }\end{array}$ & Often daily. & $\begin{array}{l}\text { Reduce load } \\
\text { during peak } \\
\text { interval. } \\
\text { Response may } \\
\text { require } \\
\text { verification. }\end{array}$ & $\begin{array}{l}1100- \\
0010\end{array}$ \\
\hline
\end{tabular}




\begin{tabular}{|c|c|c|c|c|c|c|c|c|c|c|}
\hline$\underline{\text { Response }}$ & $\underline{\mathbf{S} / \mathbf{C} / \mathbf{A}^{(1)}}$ & Description & Value $^{(3)}$ & $\underline{\text { Alternative }}$ & $\underline{\text { Cause }}$ & Duration & Urgency & Frequency & $\underline{\text { Resired }^{\text {Response }}}{ }^{(2)}$ & $\frac{\text { Example }^{(4)}}{\text { Code }^{(4)}}$ \\
\hline $\begin{array}{l}\text { Time-of-use } \\
\text { pricing }\end{array}$ & $\begin{array}{l}\text { S, C, } \\
\text { (A) }\end{array}$ & $\begin{array}{l}\text { Special case of } \\
\text { On-/off-peak } \\
\text { where signal is } \\
\text { price, or where } \\
\text { response has } \\
\text { an economic } \\
\text { meaning. }\end{array}$ & $\begin{array}{l}\text { Moderate, } \\
\text { built into } \\
\text { rate } \\
\text { tariffs. } \\
\text { Value is } \\
\text { reflected } \\
\text { in } \\
\text { incentive } \\
\text { pricing } \\
\text { structure. }\end{array}$ & $\begin{array}{l}\text { Aggregator } \\
\text { devices } \\
\text { presently } \\
\text { respond to } \\
\text { this need for } \\
\text { water heaters, } \\
\text { pool pumps, } \\
\text { and } \\
\text { thermostatic } \\
\text { loads. This is } \\
\text { thrust of AMI } \\
\text { model. }\end{array}$ & $\begin{array}{l}\text { Similar to on- } \\
\text { /off-peak but } \\
\text { with price } \\
\text { incentives or } \\
\text { penalties } \\
\text { applied. }\end{array}$ & 1-4 hours & $\begin{array}{l}\sim 10 \\
\text { minutes }\end{array}$ & $\begin{array}{l}1-2 \text { times } \\
\text { per day. } \\
\text { May be } \\
\text { different on } \\
\text { week and } \\
\text { weekend } \\
\text { days. }\end{array}$ & $\begin{array}{l}\text { Reduce load } \\
\text { during peak } \\
\text { interval. } \\
\text { Perhaps } \\
\text { increase load } \\
\text { off-peak (i.e., } \\
\text { preheat) to } \\
\text { take advantage } \\
\text { of } \\
\text { advantageous } \\
\text { prices. } \\
\text { Response may } \\
\text { require } \\
\text { verification. A } \\
\text { notification } \\
\text { response may } \\
\text { be appropriate. }\end{array}$ & $\begin{array}{l}\overline{1110-} \\
0110 \text { to } \\
1110- \\
0100= \\
1110- \\
0000 \text { to } \\
1110- \\
0010\end{array}$ \\
\hline $\begin{array}{l}\text { Critical } \\
\text { peak price }\end{array}$ & $\begin{array}{l}\text { S, C, } \\
\text { (A) }\end{array}$ & $\begin{array}{l}\text { Still another } \\
\text { variant of on- } \\
\text { /off-peak } \\
\text { control, where } \\
\text { a significant } \\
\text { energy price } \\
\text { penalty is } \\
\text { applied when } \\
\text { seasonal peaks } \\
\text { are anticipated. } \\
\text { Usually paired } \\
\text { with time-of- } \\
\text { use. May be, } \\
\text { but is not } \\
\text { necessarily } \\
\text { scheduled in } \\
\text { advance. }\end{array}$ & $\begin{array}{l}\text { Moderate } \\
\text { to High. } \\
\text { Value is } \\
\text { naturally } \\
\text { reflected } \\
\text { in } \\
\text { incentive } \\
\text { pricing } \\
\text { structure. }\end{array}$ & $\begin{array}{l}\text { Same as } \\
\text { above. }\end{array}$ & $\begin{array}{l}\text { Typically } \\
\text { responds to } \\
\text { the highest } \\
5 \% \text {, or so, of } \\
\text { system yearly } \\
\text { peak loading. }\end{array}$ & 1-4 hours. & $\begin{array}{l}\sim 10 \\
\text { minutes }\end{array}$ & $\begin{array}{l}\sim 5-10 \text { times } \\
\text { per year. }\end{array}$ & $\begin{array}{l}\text { Reduce load } \\
\text { during critical } \\
\text { peak period. } \\
\text { Response may } \\
\text { require } \\
\text { verification. A } \\
\text { notification } \\
\text { response may } \\
\text { be appropriate. }\end{array}$ & \\
\hline
\end{tabular}




\begin{tabular}{|c|c|c|c|c|c|c|c|c|c|c|}
\hline$\underline{\text { Response }}$ & $\underline{\mathbf{S} / \mathbf{C} / \mathbf{A}^{(1)}}$ & Description & $\underline{\text { Value }^{(3)}}$ & Alternative & Cause & Duration & Urgency & Frequency & $\begin{array}{c}\text { Desired } \\
\text { Response }^{(2)} \\
\end{array}$ & $\frac{\text { Example }^{\text {Code }^{(4)}}}{\underline{\text { nod }}^{(2)}}$ \\
\hline Emergency & $\begin{array}{l}\text { C, (S, } \\
\text { A) }\end{array}$ & $\begin{array}{l}\text { Very dire } \\
\text { critical peak } \\
\text { condition, but } \\
\text { not tied to } \\
\text { energy price. } \\
\text { Penalties may } \\
\text { be applied for } \\
\text { lack of } \\
\text { response. }\end{array}$ & High & $\begin{array}{l}\text { Large } \\
\text { commercial } \\
\text { and industrial } \\
\text { responses, } \\
\text { which are } \\
\text { costly. } \\
\text { Rolling } \\
\text { brown-outs. } \\
\text { "Level 3" } \\
\text { voluntary } \\
\text { response } \\
\text { plans. }\end{array}$ & $\begin{array}{l}\text { Insufficient } \\
\text { supply for } \\
\text { existing or } \\
\text { anticipated } \\
\text { load. }\end{array}$ & 1-4 hours & $\begin{array}{l}\sim 10 \\
\text { minutes }\end{array}$ & $\begin{array}{l}\text { Similar to } \\
\text { critical peak } \\
\text { price. }\end{array}$ & $\begin{array}{l}\text { Curtail non- } \\
\text { essential } \\
\text { electrical load. }\end{array}$ & \\
\hline $\begin{array}{l}\text { Real-time } \\
\text { price }\end{array}$ & $\mathrm{C},(\mathrm{A})$ & $\begin{array}{l}\text { A dynamic } \\
\text { price is } \\
\text { communicated, } \\
\text { updated at } \\
\text { relatively short } \\
\text { intervals. }\end{array}$ & $\begin{array}{l}\text { Moderate } \\
\text { to High. } \\
\text { Value is } \\
\text { naturally } \\
\text { reflected } \\
\text { in } \\
\text { incentive } \\
\text { pricing } \\
\text { structure. }\end{array}$ & $\begin{array}{l}\text { Values } \\
\text { entirely } \\
\text { addressed by } \\
\text { supply side. }\end{array}$ & $\begin{array}{l}\text { Dynamic price } \\
\text { used to reflect } \\
\text { multiple } \\
\text { objectives and } \\
\text { value streams. }\end{array}$ & Continuous. & $\begin{array}{l}\text { Intervals } \\
5 \\
\text { minutes } \\
\text { to } \\
\text { hourly }\end{array}$ & $\mathrm{n} / \mathrm{a}$ & $\begin{array}{l}\text { Modulate load } \\
\text { in inverse } \\
\text { proportion to } \\
\text { price signal. } \\
\text { Perhaps take } \\
\text { advantage of } \\
\text { price } \\
\text { opportunities } \\
\text { to preheat/pre- } \\
\text { cool. Defer } \\
\text { flexible load } \\
\text { until price } \\
\text { opportunity. } \\
\text { Notification } \\
\text { function } \\
\text { desirable for } \\
\text { price or } \\
\text { relative (i.e., } \\
\text { "high") price. }\end{array}$ & \\
\hline
\end{tabular}




\begin{tabular}{|c|c|c|c|c|c|c|c|c|c|c|}
\hline$\underline{\text { Response }}$ & $\underline{\mathbf{S} / \mathbf{C} / \mathbf{A}^{(\mathbf{1})}}$ & Description & Value $^{(3)}$ & Alternative & $\underline{\text { Cause }}$ & Duration & Urgency & Frequency & $\underline{\underline{\text { Desired }}} \underset{\text { Response }^{(2)}}{ }$ & $\frac{\text { Example }}{\text { Code }^{(4)}}$ \\
\hline $\begin{array}{l}\text { Capacity } \\
\text { limit }\end{array}$ & $\mathrm{C}$ & $\begin{array}{l}\text { Premise or } \\
\text { regional power } \\
\text { capacity limit } \\
\text { is imposed and } \\
\text { enforced. }\end{array}$ & $\begin{array}{l}\text { Unknown. } \\
\text { Practice } \\
\text { in Europe } \\
\text { but not in } \\
\text { the U.S. }\end{array}$ & $\begin{array}{l}\text { Manage } \\
\text { capacity at } \\
\text { system level } \\
\text { instead of at } \\
\text { premise or } \\
\text { neighborhood } \\
\text { level. }\end{array}$ & $\begin{array}{l}\text { Premise } \\
\text { capacity is } \\
\text { limited to } \\
\text { reduce system } \\
\text { peak load and } \\
\text { to protect } \\
\text { distribution } \\
\text { equipment. }\end{array}$ & Continuous. & $\begin{array}{l}\sim 1 \\
\text { second? }\end{array}$ & Intermittent. & $\begin{array}{l}\text { Share or defer } \\
\text { load when } \\
\text { premise } \\
\text { capacity limits } \\
\text { are met. } \\
\text { Coordination } \\
\text { and } \\
\text { prioritization } \\
\text { may be } \\
\text { required. }\end{array}$ & \\
\hline
\end{tabular}

Notes:

(1) $\mathrm{S}=$ Scheduled $\mathrm{C}=$ Communicated; and $\mathrm{A}=$ Autonomous

(2) Distributed onset and release of responses is preferred to maintain or reestablish electrical load diversity.

(3) Monetary values can be estimated or known for specific grid regions. This is left as a future refinement.

(4) Pin Codes:

Request Condition:

0 - Inactive - no response is being requested - idle state. 1 - Active - a response is being requested by the grid.

Expected Response Duration:

0 - Short - need for response should be less than 1 minute and may never exceed 10 minutes.

1 - Long - need for response may exceed 10 minutes.

Request Urgency:

0 - Slow-response to the request should occur promptly, but the response may be deferred for up to 10 minutes.

1 - Fast—response to request should be completed as quickly as possible as and never longer than 0.5 second.

Request Frequency:

0 - Infrequent - response is expected to be requested not more than 52 times per year (once per week, on average).

1 - Frequent - response is expected to be requested more often than once per week and may be requested continuously.

Load-Response Request: (These are stated from perspective of load. Supply resources should interchange the words "reduce" and "increase".)

00 - Reduce real power

01 - Increase real power

10 - Reduce reactive power

11 - Increase reactive power

Request-Level Modifier:

00 - Not at all / Normal

$01-$ A little / Normal + 1 SD

$11-$ A lot / Normal + 2 SD

$10-$ As much as is possible / Normal + $3 \mathrm{SD}$ 


\section{Appendix $\mathrm{H}$}

\section{GWAC Stack Assessment of PinBus}





\section{Appendix H: GWAC Stack Assessment of PinBus}

Table H.1. Conformance to GridWise ${ }^{\mathrm{TM}}$ Architecture Council (GWAC) Stack (Blue-Device Responsibility; Green-Device Interface Responsibility; Purple-Premises Responsibility; Yellow-Utility Entity Responsibility)

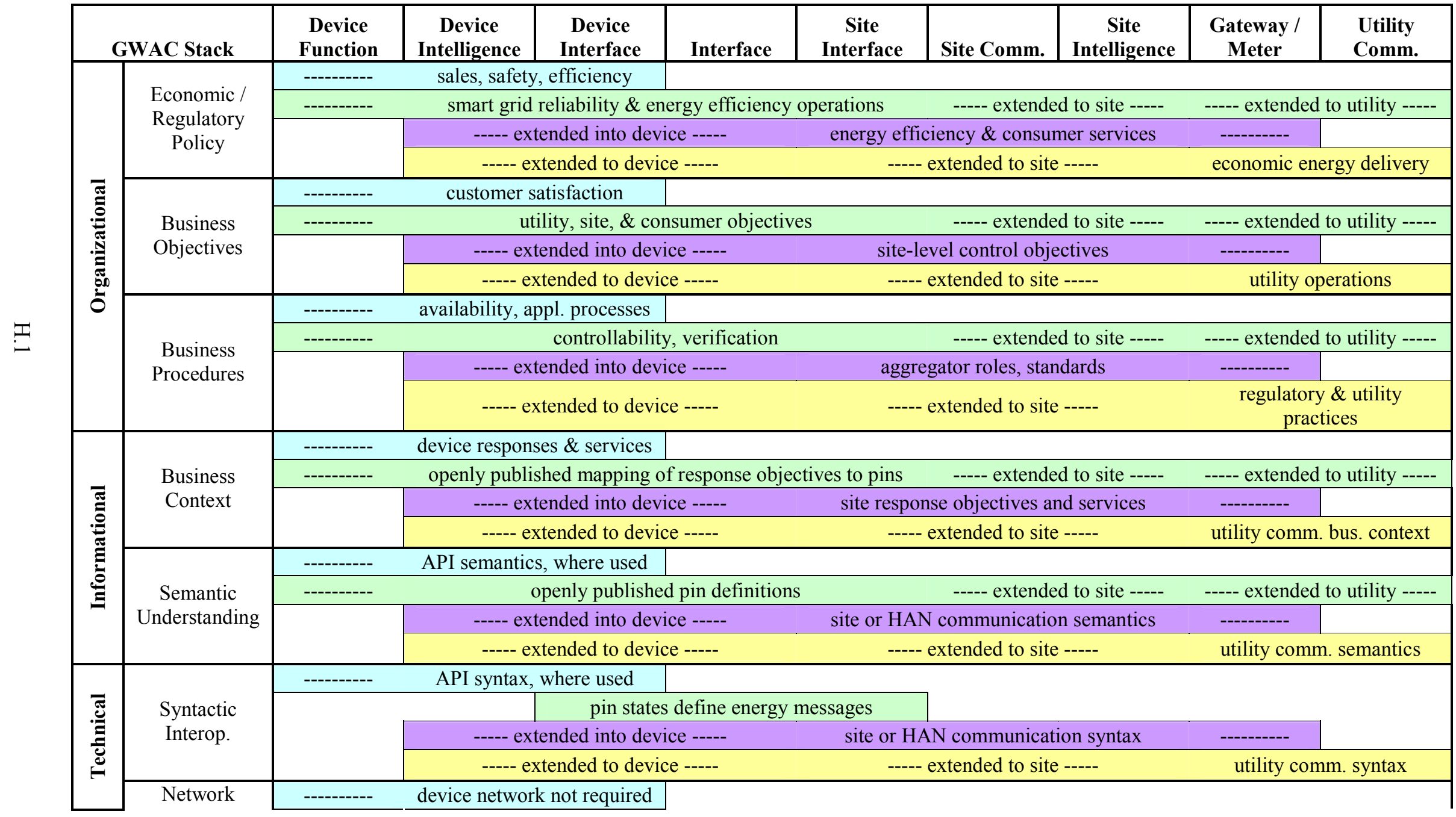




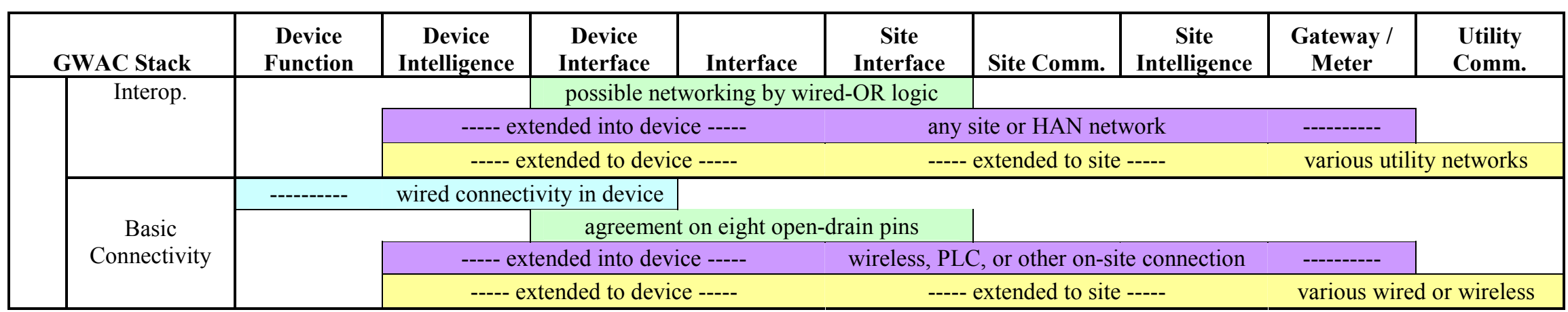




\section{Appendix I}

\section{Block Diagram - PinBus Interoperability Demonstration}





\section{Appendix I: Block Diagram - PinBus Interoperability Demonstration}

\section{Pinbus $^{\mathrm{TM}}$ Interoperability Demonstration}

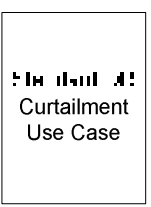

$\Xi$

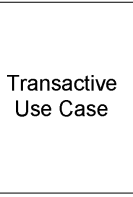

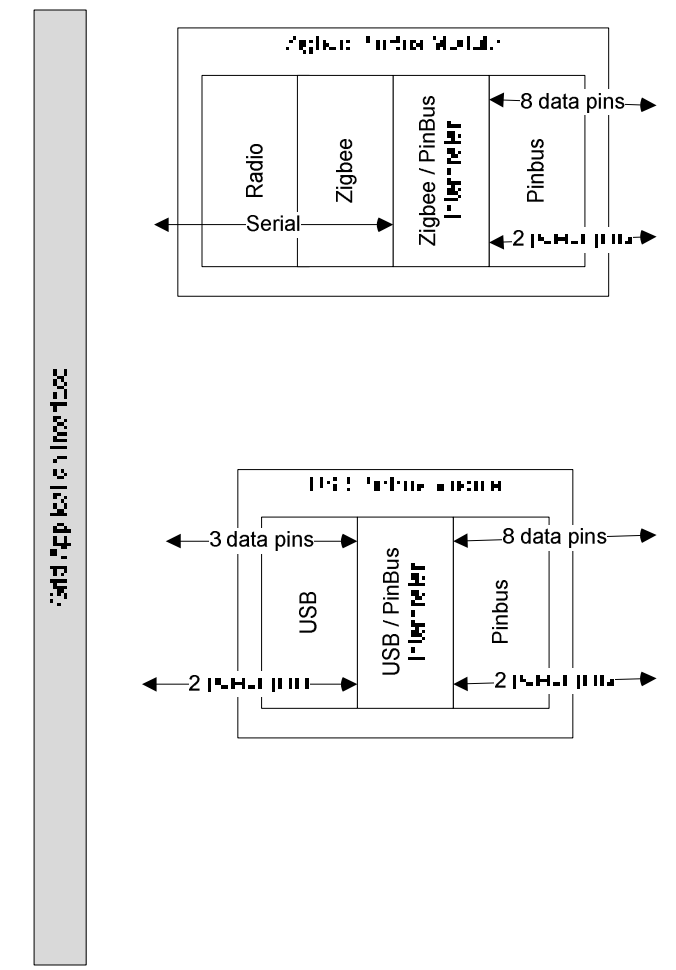

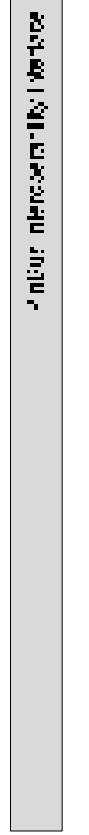

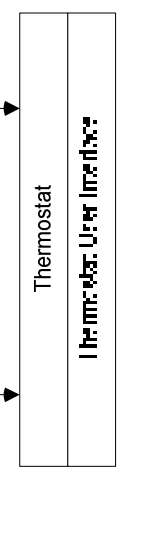
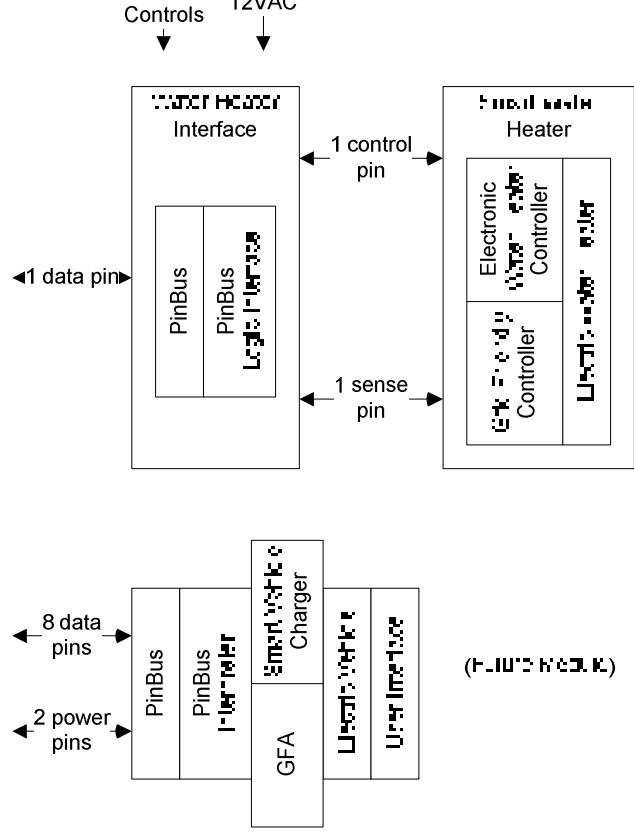

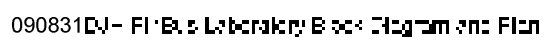

Figure I.1. Bock Diagram of Planned Laboratory Demonstration Components 


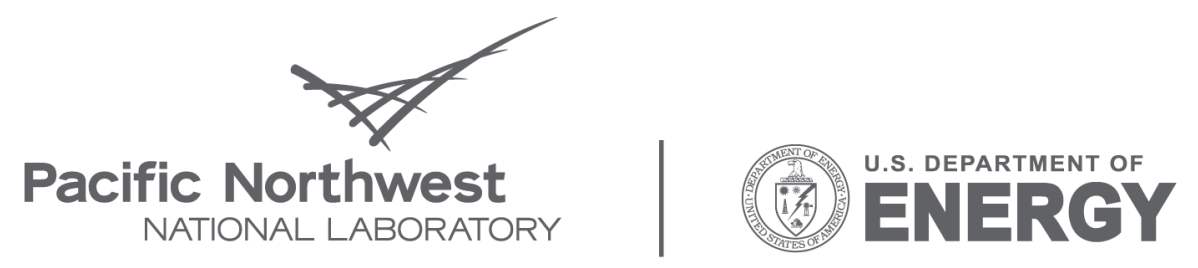

Proudly Operated by Battelle Since 1965

902 Battelle Boulevard

P.O. Box 999

Richland, WA 99352

1-888-375-PNNL (7665)

www.pnl.gov 